BULLETIN Bulletin hispanique

HispaniQuE Université Michel de Montaigne Bordeaux

114-1 | 2012

Varia

\title{
Estructura y argumentación de España defendida, de Francisco de Quevedo
}

Antonio Azaustre Galiana

\section{(2) OpenEdition}

Journals

Edición electrónica

URL: http://journals.openedition.org/bulletinhispanique/1633

DOI: 10.4000/bulletinhispanique.1633

ISSN: 1775-3821

Editor

Presses universitaires de Bordeaux

Edición impresa

Fecha de publicación: 1 junio 2012

Paginación: 117-152

ISBN: 978-2-86781-812-7

ISSN: 0007-4640

Referencia electrónica

Antonio Azaustre Galiana, "Estructura y argumentación de España defendida, de Francisco de Quevedo », Bulletin hispanique [En línea], 114-1 | 2012, Publicado el 01 junio 2015, consultado el 19 abril 2019. URL : http://journals.openedition.org/bulletinhispanique/1633 ; DOI : 10.4000/ bulletinhispanique. 1633 


\title{
Estructura y argumentación de España defendida, de Francisco de Quevedo
}

\author{
Antonio Azaustre Galiana \\ Universidad de Santiago de Compostela ${ }^{1}$
}

Ce travail analyse la structure et les procédés argumentatifs de España defendida, une auvre historique précoce et inachevée de Quevedo dans laquelle il développe un panégyrique de l'Espagne et une réfutation des attaques et calomnies de divers écrits étrangers.

Este trabajo analiza la estructura y recursos de argumentación de España defendida, temprana e inacabada obra histórica de Quevedo en la que desarrolla un panegírico de España y una refutación de las censuras que contra ella lanzaron diversos escritos extranjeros.

This paper will analyze the structure and argumentative strategies of España defendida, an early historical work, left uncompleted, by Quevedo, in which he develops a panegyric of Spain and a rejection of the attacks and calumnies of diverse foreign writings.

Mots-clés : Quevedo, rhétorique, argumentation.

$\mathrm{E}$ STA obra temprana de Quevedo se ha conservado manuscrita en una copia autógrafa cuya dedicatoria se fecha en $1609^{2}$. Su final abrupto, el apreciable número de folios en blanco y las notas contenidas en diversos lugares del manuscrito apuntan a un texto en proceso de revisión y ampliación ${ }^{3}$. Ello

1. Este trabajo se integra en las actividades del proyecto de investigación del Ministerio de Ciencia e Innovación con referencia FFI2010-16903. En 2012 se publicará una nueva edición de España defendida, al cuidado de Victoriano Roncero (Pamplona, Eunsa, 2012). Gracias a su amabilidad y a la de la editorial, he podido tener acceso a una versión no paginada, lo que me ha permitido incluir algunas de sus aportaciones (Roncero, 2012), aunque no citar por su texto.

2. Biblioteca de la Real Academia de la Historia, colección Salazar, 9/805, olim L-76. Más precisiones sobre la fecha de composición ofrece Roncero, 2012, apdo. II de su estudio preliminar.

3. Véanse más detalles en Selden Rose, 1916, pp. 5-7, Jauralde, 1998, pp. 961-962, y Roncero, 2012, apdo. II del estudio preliminar. Según Jauralde, 1998, pp. 244-245, parece tratarse de una segunda copia, pues, aun con algunas tachaduras y enmiendas, el texto discurre con apreciable fluidez a lo largo de sus folios. Roncero, 2012, apdo. III, cree que sería un primer borrador del que habría de sacarse una copia en limpio. Los folios en blanco se encuentran al final de cada 
hace difícil determinar lo que habría sido el resultado final, tanto en lo que atañe al cuidado en su organización como al nivel de erudición de Quevedo en los diferentes temas que aborda ${ }^{4}$.

La intención de este escrito, explícita desde su propio título, es la defensa de España ante las calumnias que, según Quevedo, vertían sobre ella las naciones extranjeras ${ }^{5}$. En consecuencia, su estructura y argumentación reunirán rasgos propios del panegírico y de la refutatio ${ }^{6}$.

El afán refutador y polemista es uno de los rasgos característicos de la historiografía hispana del XVII, y se desarrollará en dos vertientes que también se observan en este escrito de Quevedo: por un lado, la contestación a los ataques extranjeros; por otro, los matices a las inexactitudes y fantasías que proliferaban en numerosos textos historiográficos ${ }^{7}$.

El panegírico de países y ciudades era un aspecto muy tratado en la retórica de la antigüedad, pues constituía una de las vertientes más destacadas del género epidíctico o demostrativo; las laudes Italiae y laudes Romae atestiguan su temprano cultivo literario ${ }^{8}$. Vinculada a esta tópica se halla la tradición literaria de las laudes Hispaniae. Aunque existen menciones laudatorias a España en obras anteriores ${ }^{9}$, se suele considerar como primer panegírico De laude Spaniae, incluido por san Isidoro al comienzo de De origine Gothorum (c 624). Con él se abre una rica senda de elogios medievales que se adentra en el Renacimiento y tendrá su continuación en los Siglos de Oro ${ }^{10}$.

capítulo y del manuscrito. Su espacio se reserva para diversas anotaciones, como parece indicar la nota contenida en el f. 12v, al final del capítulo 1 y antes de dos folios en blanco: «esto blanco se deja para emmendar i añadir el capitulo pasado conforme a las letras del abeze correspondientes aquí i en el texto" (f. 12v). Roncero, 1997, pp. 216-220, y Plata, 2001, p. 211 advirtieron ya este modo de proceder de Quevedo en España defendida y en la traducción de las Controversias de Séneca el Viejo, respectivamente.

4. Sobre estas cuestiones, véanse los trabajos de Jauralde, 1997, 1998, pp. 207-219 y 244245, y Roncero, 2000, pp. 13-119, y 2012, apdo I del estudio preliminar.

5. El título completo es «España defendida i los tiempos de aora de las calumnias de los noveleros i sediciosos» (f. 1r).

6. El conocimiento de las técnicas de la refutatio era habitual en retórica, donde se abordaba dentro de las partes del discurso y también entre los ejercicios. Como parte del discurso (Cicerón, De inventione, 1, 14, 19; Quintiliano, Institutio Oratoria, 3, 9, 1), la refutatio sigue a la probatio: el orador, tras demostrar la verdad de su punto de vista, rechaza y demuestra lo inconsistente del contrario. Además de utilizar todo el abanico de probationes, el orador recurre con frecuencia a la amplificatio y su vehemencia en sus ataques al contrario (cfr. Quintiliano, Institutio Oratoria, 5 , 13). En el ámbito de los ejercicios retóricos también se reservó un espacio para ella. Hermógenes, por ejemplo, le dedica su ejercicio número cinco, donde muestra con brevedad los caminos para invalidar el tema que se ha propuesto al alumno. Las esferas de aplicación de sus técnicas son muchas: la crítica de la falsa concepción de la historia y del mundo, de la falsa erudición, y las más pragmáticas de los ámbitos político y judicial. Véase también Lausberg, 1960, $\$ \$ 1122$ 1125 y 262, cuadro donde se observa la integración de la refutación dentro de la argumentatio en diversos tratados de retórica clásica.

7. Véase Sánchez Alonso, 1941, vol. 2, pp. 353-372.

8. Curtius, 1981, p. 228.

9. Véase Roncero, 1993, pp. 81-83.

10. Davis, 1935 y Tate, 1982, ofrecen detallada información. 
En cuanto a las características de estas obras, De laude Spaniae de san Isidoro se centraba en las bondades del suelo hispano y en su riqueza de cultivos, ganados y metales. Se vinculaba así a las referencias de autores como Estrabón o Plinio, que describieron la geografía y estructura económica de Hispania dando cuenta de la prosperidad de la que disfrutó con la romanización ${ }^{11}$. A partir de san Isidoro se fueron incorporando a los panegíricos otros aspectos como el elogio de personajes ilustres -en especial, hombres de letras y religiosos- y la superioridad de España frente a otras naciones. Así, Lucas de Tuy pone más acento en el elogio de las gentes y en la esfera religiosa, y subraya el haber tenido filósofos y escritores de la talla de Séneca o Lucano, o las visitas que a Hispania hicieron san Pablo y Santiago. La superioridad sobre naciones extranjeras, a menudo presentadas como enemigas, aparece ya en el Poema de Fernán González y en las Décadas de Nebrija ${ }^{12}$.

La España defendida de Quevedo se apoya así en una rica tradición retórica e historiográfica. En lo que sigue se analizará cómo su estructura y argumentación responden en buena medida a rasgos vinculados a la refutatio y al panegírico de países y ciudades ${ }^{13}$.

El texto consta de unos preliminares literarios y seis capítulos, el último de los cuales termina de forma abrupta. Desde ahí el manuscrito continúa con una serie de anotaciones autógrafas sobre diferentes aspectos que se supone cabría matizar o ampliar, lo que de nuevo muestra el carácter provisional con que debe considerarse lo que conservamos de la obra.

\section{Preliminares literarios}

Están formados por dos dedicatorias (a Felipe III y al lector) y una explicación de la "Ocasión y causas del libro». Es un diseño acorde con las exigencias de una captatio benevolentiae y de explicar el asunto subrayando su interés. Antes de estas tres secciones se incluye una cita bíblica de Jeremías adecuada a la intención refutatoria de la obra ${ }^{14}$.

Como resulta preceptivo, la primera de las dedicatorias es la dirigida al monarca. De breve extensión, ofrece una clásica organización que combina la humilitas del autor con la alabanza de Felipe III y justifica la obra como una necesaria defensa de su calumniada nación. Entre esos clásicos rasgos, acaso pueda destacarse argumentativamente el pasaje donde se funden tales

11. Blázquez Martínez, 1971, ha estudiado estas cuestiones.

12. Véase el comentario de Carrera de la Red, 1988, p. 74: «El tono de ardiente patriotismo que va a caracterizar las declaraciones de la mayoría de los gramáticos de lenguas vulgares en el siglo XVI sobre la finalidad de su obra ya está presente en Nebrija, para quien su primer pensamiento fue siempre "engrandecer las cosas de nuestra nación"”.

13. Más detalles sobre la relación de España defendida con las laudes Hispaniae en Roncero, apdo. I. II. del estudio preliminar.

14. Quevedo da el texto hebreo y la siguiente traducción castellana: «abrieron sobre nosotros sus bocas todos nuestros enemigos; o mejor: desbocáronse contra nosotros los que nos persigen» (p. 21, f.1r). Sobre las fuentes de esta cita, véanse Caminero, 1979, p. 63, y Roncero, 2000, p. 64. 
intenciones. Para Quevedo, los gloriosos hechos protagonizados por Espańa constituyen su principal defensa; ante ellos, el intento de su escrito queda reducido a la modesta osadía de un ferviente patriota:

me e atreuido a responder por mi patria y por mis tiempos; cosa en que la verdad tiene hecho tanto, que solo se me deuera la osadia de quererme mostrar mas zeloso de sus grandezas, siendo el de menos fuerzas entre los que pudieran hazerlo (p. 21, f 1v) ${ }^{15}$

También es breve la dedicatoria "Al letor» (ff. 2r-3r), aunque no tanto como la dirigida al rey. En la presentación de una obra, una de las clásicas vías para lograr la captatio benevolentiae es que el escritor se muestre modesto en sus cualidades o pequeńo para la empresa que acomete ${ }^{16}$; pero otra de ellas es despertar el interés sobre el texto que ofrece. Sobre este punto insiste esta segunda dedicatoria, donde el panegírico de las glorias de Espańa se presenta como un propósito necesario no solo por los ataques de los extranjeros, sino también porque los escritores españoles no han desarrollado tal empresa ${ }^{17}$ :

La poca ambizion despańa, bien que sean culpados los injenios de ella, tienen en manos del olvido las cosas que merezieron mas clara voz de la fama. Tal fue la ingratitud de sus escritores, i el descuiido que parezio desprezio a los estraños, juzgando faltaua que escriuir i quien escriuiese; i asi padezio la reputazion de todos, i sin duda vbieran perdido la memoria como la voz, si fuera en su mano el olvido como el silenzio (p. 22, ff. 2r-2v).

Para enmendar esta falta, Quevedo subraya la novedad de su obra recurriendo al tópico de ofrecer cosas nunca antes dichas ${ }^{18}$; al mismo tiempo, se anticipa a las censuras que el texto pueda despertar, lo que avanza la importancia que la refutación de autores y juicios contrarios tendrá a lo largo de sus páginas. Añádase a lo anterior el reforzar la veracidad de sus contenidos presentándose como un testigo de vista ${ }^{19}$ :

bien se a quantos contradigo, i reconozco los que se an de armar contra mi; mas no fuera io español si no buscara peligros, despreziandolos antes para

15. Citaré los pasajes de España defendida indicando la página de la edición de Robert Selden Rose incluida en la bibliografía y señalando también el folio del autógrafo. Se han hecho cambios en la puntuación para facilitar la lectura.

16. Más detalles sobre este tópico del exordio ofrece Curtius, 1981, pp. 127-131.

17. Es esta una idea que ya se había empleado en otros textos historiográficos y literarios. Aparecía, por ejemplo, en los Loores de los claros varones de España, de Fernán Pérez de Guzmán, y en las anotaciones de Herrera a la poesía de Garcilaso, tal y como indicaron Davis, 1935, p. 156; Lawrance, 1985; Binotti, 1995, p. 26, y Roncero, 2000, p. 87. Herrera habla de ello ya en su comentario a la voz soneto; véanse las pp. 73-74 de su edición de Garcilaso (1580). Como se indicará más adelante (nota 82 ), la propia historiografía hispana justificará esa ausencia por la magnitud de los hechos de armas españoles.

18. Véase Curtius, 1981, pp. 131-132.

19. El testimonio es una prueba extratécnica que ofrece un grado muy elevado de seguridad; Peraita, 1997, p. 172, ya señaló este rasgo del prólogo de España defendida, y estudió (Peraita, 1997, pp. 172-185) el valor de este recurso en la historiografía y en otras obras quevedianas como Grandes anales de quince días. 
venzerlos despues, i lo hare con estas memorias, que seran las primeras que, desnudas de amor v miedo, se abran visto sin disculpa de relaziones i istoria (si este nombre mereze), en que se leeran los ojos i no los oidos del autor (p. 22, f. 3 r).

Los preliminares se cierran con la explicación de la «Ocasión y causas del libro» (ff. 3r-12v). A modo de divisio retórica ${ }^{20}$, Quevedo anticipa la disposición de esta sección e indica que refutará las censuras de los extranjeros, pero también las de los propios españoles que ofenden a su nación:

No ambizion de mostrar injenio me busco este asumpto; solo el ver maltratar con insolenzia mi Patria de los estranjeros, i los tiempos de aora de los propios, no abiendo para ello mas razon de tener a los forasteros imbidiosos, i a los naturales que en esto se ocupan despreziados; i callara con los demas, si no viera que buelben en lisençia desvocada nuestra vmildad i silenzio (p. 22, f. 3v) ${ }^{21}$.

De acuerdo con la divisio, el resto de este preliminar se dispone en dos secciones que reúnen ejemplos de censuras contra Espańa. Respetando el ordo naturalis, Quevedo las ordena de menor a mayor gravedad, y comienza con ejemplos de calumnias extranjeras: José Justo Scalígero, Marco Antonio Muret y, sin citarlo explícitamente, el cardenal Baronio: al primero le achaca «dezir mal de Quintiliano, Lucano i Seneca, i llamarlos Pingues isti cordubenses» (p. 23, f. 4r $)^{22}$; pero es justo decir que las frases que le dedica poco antes parecen orientar las críticas al terreno moral y reconocer su monumental erudición:

20. La divisio era la parte final del exordio, donde se avanzaban los aspectos que se iban a tratar en el discurso. De su conveniencia habla Quintiliano, Institutio Oratoria, 4, 2, 47-50.

21. Como se observa en la cita, precede a esta declaración de intenciones una tópica humilitas que niega como finalidad de la obra el alarde de erudición o ingenio. Pero Quevedo ya ha manifestado antes esta idea, por lo que cabe pensar en una irónica expresión de lo que en realidad es uno de sus propósitos. Jauralde, 1997, 1998, p. 208, y Roncero, 2000, p. 16, analizan y valoran las intenciones de Quevedo tanto en lo que concierne a la defensa de Espańa como a su intento erudito.

22. La cita pertenece al comienzo de las notas que Scalígero elaboró para su edición del poema Aetna (Leyden, Lindenbruch, 1595). Allí atribuye la autoría del poema a Publio Cornelio Severo, a quien compara favorablemente con los poetas cordobeses: «Ex quo poemate, quod nobis ex omnibus illis scriptoris operum naufragio reliquum est, potes advertere, quantus fuerit ille vir in penetralibus Heliconis: quamque melius nobiscum ageretur, quam isti pingues cordubenses Poetae,

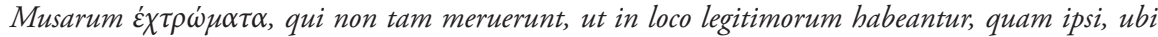
legitimos desideramos, in vacuum venerunt» (p. 78). El juicio negativo sobre los poetas cordobeses había sido ya manifestado por Cicerón en el capítulo 10 de su Pro A. Licinio Archia Oratio: «Quid a Q. Metello Pio, familiarissimo suo, qui civitate multos donavit, neque per se neque per Lucullus impetravisset? Qui praesertim usque eo de suis rebus scribi cuperet, ut etiam Cordubae natis poetis pingüe quiddam sonantibus atque peregrinum tamen aures suas dederet». Cicerón se refería a los poetas cordobeses de su tiempo, el sonido de cuyos versos consideraba grosero y raro por foráneo. Este pasaje de Cicerón fue bastante citado; lo menciona, por ejemplo, Aldrete en su obra Del origen y principio de la lengua castellana ò romance que oi se usa en España (lib. I, cap. XIV, p. 88 de la edición de 1606). Lucano y Séneca fueron los más destacados escritores cordobeses porteriores a Cicerón. Munro, 1867, p. 26, considera que Scalígero refleja en la citada nota su mala opinión de Lucano. 
«i vi a Josepho Escalijero por Olanda, hombre de buenas letras i de mala fe, cuia cienzia i dotrina se zifro en saber morir peor que viuio» (p. 23, f. 4r) ${ }^{23}$. El procedimiento utilizado por Quevedo para censurar al humanista es la socorrida fragmentación de la cita, seleccionando aquella parte que mejor se adecuaba a sus intereses ${ }^{24}$.

La segunda censura se dirige al humanista francés Marco Antonio Muret, que en las últimas décadas del siglo XVI había publicado diversos trabajos, entre ellos ediciones y comentarios a poetas latinos como Catulo. En el prólogo de su edición, Muret comparaba a Catulo y Virgilio con los hispanos Lucano y Marcial y consideraba superiores a aquellos, viendo a los hispanos como representantes de una Edad de Plata que no había alcanzado el valor de sus antecesores $^{25}$. La crítica de Quevedo se acerca por momentos a la invectiva, y recurre entonces a la descalificación directa de su oponente, a quien llama «charlatán francés» y «blasfemo i desvergonzado» (p. 23, ff. 4r y 4v) ${ }^{26}$. Con una metáfora que apunta su proverbial dominio de la agudeza («roedor de autores», p. 23, f. 4r), Quevedo alude negativamente a la faceta de Muret como editor y comentarista. Con esta misma intención de descalificar sus comentarios, combina la paradoja con el argumento a comparatione, para afirmar que los comentarios de Muret a pasajes de Catulo son aún peores que los lugares que ha dejado oscuros por no comprenderlos:

llamar en vn comento a Catulo, con el qual, en lugar de darle a entender a otros, muestra que el no le entendio, i lo confiesa asi en muchas partes; i le va mejor al poeta que en las que, pensando le entiende, le lebanta testimonios i le desonrra (p. 23, ff. 4r-4v).

El tercer autor extranjero al que ataca Quevedo es el cardenal Cesare Baronio; el asunto que ahora le atañe, más trascendente que las anteriores disputas literarias. Se trata de la venida del apóstol Santiago a España, que el cardenal Baronio había rechazado en sus Annales Ecclesiastici (cf. España defendida, ff. $5 r-5 v)^{27}$. Quevedo refuta esa opinión basándose en la ortodoxia religiosa: las

23. Scalígero murió en 1609. Aunque la referencia a los poetas cordobeses pertenece a otro texto de Scalígero (véase la nota anterior), Quevedo probablemente admiró su monumental Thesaurus Temporum o Coronicon de Eusebio, publicado en 1606, y al que se aludirá en el capítulo II de España defendida (p. 30, f. 18r). Jauralde, 1997, pp. 47-48, 1998, pp. 209-210, estudia la deuda de Quevedo con esta obra, y juzga España defendida como un joven intento de competir con dichos trabajos, del cual Quevedo no salió airoso por lo que atañe al nivel de profundidad en el tratamiento de los asuntos.

24. Es un procedimiento muy común en el uso argumentativo de la cita. Por lo que atañe a Quevedo, véase un ejemplo en Azaustre, 2005, p. 326-327.

25. Selden Rose, 1916, pp. 7-8, reproduce el pasaje.

26. Jauralde, 1997, pp. 48-50, 1998, pp. 210-212, contextualiza y pondera la labor filológica de Muret en la recuperación de los clásicos y, frente a ella, califica de «un tanto frívola» la actitud de Quevedo.

27. La venida del apóstol Santiago a España fue una cuestión historiográfica de gran importancia desde el último tercio del siglo XVI, y aparecerá más tarde en dos memoriales de Quevedo en defensa de Santiago como patrón de España. Véanse más detalles sobre esta cuestión 
invalida por contrarias a la fe y las tradiciones, y las califica de herejías de un envidioso.

Tras ocuparse de los extranjeros que habían ofendido a España, Quevedo lamenta aún más que esta haya carecido de defensores y, por el contrario, la historiografía hispana haya continuado esa senda de calumnias, negando algunos autores incluso la existencia del Cid y de Bernardo del Carpio ${ }^{28}$. Cuando aborda estas cuestiones, Quevedo no profundiza en documentos ni autores para demostrar el error de tales afirmaciones. Su refutatio se apoya más en su habilidad retórica para desmontar ideas y argumentos. Así, en el primero de los pasajes abajo citados recurre a un expresivo retruécano para desautorizar a quienes negaban la existencia del Cid; en el segundo, admitirá la existencia de algunos textos contrarios (concessio) para para ponderar la mayor cantidad de documentos a favor de la existencia de dichos héroes:

Llegose a esto ver que, quando aguardaban ellos a tan grandes injurias alguna respuesta, vbo quien escriuio, quiza por lisonjearlos, que no auia auido Çid; i, al rebes de los griegos, alemanes i franzeses, que hazen de sus mentiras i sueños verdades, el hizo de nuestras verdades mentiras (p. 23, f. 5v).

Demos que se halle vn libro v dos v tres que digan que no vbo Çid ni Vernardo, ¿por qué causa an de ser creidos antes que los muchos que dizen que los vbo?; si no es que la malizia ańada autoridad, no se qual tengan mas (p. 24, f. 6v).

Y es que a Quevedo no le interesa aquí adentrarse en delicadas polémicas historiográficas, sino subrayar cuánto más graves son las calumnias de los propios españoles y la falta de escritos en defensa de su patria. Insistir en ello le servirá para lograr uno de los objetivos del exordio, presentar su obra como necesaria y novedosa:

y sobre la postura del cardenal Baronio en Ruiz Castelao, 1985, pp. 38 y 59-61, Pérez González, 1998, y Jauralde, 1997, pp. 50-51, 1998, pp. 212-213 y 248-249.

28. Es difícil precisar a quién se refiere Quevedo en concreto. En mayor o menor medida, diversos historiadores de los siglos XVI y XVII recelaron de los hechos fabulosos atribuidos a héroes como el Cid o Bernardo del Carpio, cuando no de su misma existencia. Menéndez Pidal, 1929, pp.11-15, advirtió del escepticismo que entre historiadores de los siglos XV a XVII suscitaron diversas gestas adjudicadas al Cid. Mariana (Historia general de España, lib. VII, cap. XI) y, en mayor medida, Ambrosio de Morales (Los cinco libros postreros de la Corónica general de España que continuaba Ambrosio de Morales, lib. XIII, caps. XLVII y XLVIII) desconfiaron de muchas informaciones relativas a la batalla de Roncesvalles y de la presencia en ella de Bernardo del Carpio. En Excelencias de la Monarchía y Reyno de España (cap. II, f. 12r), López Madera señala a Ambrosio de Morales como autor que aclara muchas confusiones y falsedades en relación con los sucesos atribuidos a Bernardo del Carpio. Otros autores que atacaron la historicidad de Bernardo del Carpio fueron Pedro Mantuano (Advertencias a la Historia de Juan de Mariana, Milán, 1611) y, posteriormente, José Pellicer. Para Roncero, 2012, apdo. II, Quevedo podría referirse a las Advertencias de Pedro Mantuano, lo que indicaría que seguía trabajando en España defendida en 1611. 
que el enemigo no es mucho que se muestre curioso, que es lo mismo que malevolo. Asi lo dijo el poeta: "curiosus nisi malevolus» ${ }^{29}$; pero el hijo de la republica, lo que le toca es ser propizio a su patria (p. 24, ff. 6v-7r).

La parte final de este preliminar se ha construido como una vehemente peroratio. Primero Quevedo ataca a los extranjeros echando mano de los vicios que se les achacaban en su tiempo ${ }^{30}$ : sodomía de los italianos y afición a la bebida de los alemanes, además de la herejía común a muchos países del centro y norte de Europa:

¿Quién no nos llama varbaros? ¿Quién no dize que somos locos, inorantes i soberbios, no teniendo nosotros vizio que no le devamos a su comunicazion de ellos? ¿ Supieran en Espańa que ley abia para el que lasçiuo ofendia las leyes de la naturaleza, si Italia no se lo vbiera enseńado? ¿vbiera el brindiz repetido aumentado el gasto a las mesas castellanas, si los tudescos no lo vbieran traido? Oziosa vbiera estado la santa inquisizion, si sus Melantones, Calvinos, Luteros i Zuinglios i Besas no vbieran atreuidose a nuestra fe. I, al fin, nada nos pueden dezir por oprobio, si no es lo que ellos tienen por onrra, i, aberiguado, es en nosotros imitazion suia (pp. 24-25, ff. 7r-7v).

Esta vehemente censura prepara la exhortación final, que combina la necesaria alabanza a Felipe III con la necesidad de defenderse ante tales ofensas extranjeras y, sobre todo, ante la falta de escritos propios en esa línea. Así se insiste una vez más en la novedad de la presente obra:

Ia pues es razon que despertemos i logremos parte del ozio que alcanzamos en mostrar lo que es España, i lo que a sido siempre, i juntamente que nunca tan gloriosa triumpho de letras i armas como oi, gobernada por don Philipe III nuestro seńor ${ }^{31}$. Tenemos dos cosas que llorar los espańoles: la vna, lo que

29. Cita de Plauto, Stichus, 208: «nam curiosus nemo est, quin sit malevolus» ("no hay ningún curioso que no sea malvado").

30. Véase Herrero García, 1966, pp. 202-225.

31. El manuscrito continúa aquí con unas líneas tachadas donde se censura la figura del Padre Mariana, que había sido encarcelado por sus opiniones contrarias a la política monetaria del monarca, las cuales manifestó en el tratado cuarto de su obra De Ioannis Marianae e Societate Iesv Tractatus VII, que contiene los siguientes tratados: De adventu Iacobi Apostoli in Hispaniam, Pro Editione vulgata; De spectaculis; De monetae mutatione; De die mortis Christi; De annis arabum; De morte et immortalitate (Köln, 1609). El texto tachado es el siguiente: «a pesar de los discursos del padre Mariana, que desde su çelda quiso, no gobernar el mundo, sino escandalizarle, con saber que la advertenzia es permitida, pero no la sediziosa murmurazion, i mas de hombre que ni trata el estado ni la rrazon dél, hombre apartado de todo arrepentimiento, pues si de la historia que hizo le vbiera tenido, no vbiera atrevidose a cosa en que le tendra tarde i por dificultoso camino; que en esto paran los que • pues los tenemos» (p. 25, ff. 7v-8r). Roncero, 1997, pp. 216217, cree que Quevedo se arrepintió de la dureza de ese párrafo contra Mariana, a quien, según Tarsia, habría ayudado en la revisión de fragmentos hebreos de la Biblia de Arias Montano. En su edición de 2012, apdo. III, señala como posible causa de la censura a Mariana sus opiniones sobre el levantamiento popular y el tiranicidio contenidas en De rege et regis institutione (1599). Jauralde, 1998, p. 256, piensa que el encuentro con Mariana en Toledo pudo haber influido en que tachase esa parte del texto, y acaso también en que no hubiese continuado la obra, aunque en este punto considera sobre todo lo complejo e ingente de la empresa. Más detalles sobre la 
de nuestras cosas no se a escrito, i lo otro, que hasta aora lo que se a escrito a sido tan malo, que viuen contentas con su olvido las cosas a que no se an atrevido nuestros coronistas, escarmentadas de que las profanan i no las celebran (p. 25, ff. 7v-8v).

La sección "Ocasión y causas del libro» se cierra con la referencia a un escrito contra la actuación española en ultramar (f. $8 \mathrm{v})^{32}$. Aunque el pasaje añade una nueva perspectiva -la de las críticas que traspasan los mares y llegan al Nuevo Mundo-, es necesario reconocer que no parece este el lugar más apropiado para incluirla, pues el final de un exordio resulta más adecuado para la recapitulación y vehemencia que mostraban los párrafos anteriores. Se observa así una tendencia a la digresión que desequilibra la estructura. Esta tendencia aparecerá en otras partes de la obra, y refleja su carácter de texto necesitado de revisión.

Tras los preliminares literarios, la obra se organiza en seis capítulos. Si se repasan sus epígrafes, se aprecia cómo buena parte de ellos se centra en las tópicas características del elogio de ciudades y países: el emplazamiento geográfico y su clima, las riquezas que atesoran, su antigüedad, los hombres destacados en ciencias y artes, sus costumbres... ${ }^{33}$ A ellos cabe añadir la importante presencia de la cuestión lingüística, a la que dedica Quevedo el cuarto capítulo, el más extenso y trabajado del texto que conservamos. Este rasgo la acerca a una corriente común al humanismo europeo desde el Renacimiento, período en el que el estudio de las lenguas clásicas convive y polemiza en ocasiones con la alabanza de las vernáculas.

\section{CApítulo PRIMero: «Despaña, su Sitio, ÇIElo, FERTILIDAD I RIQUEZA» (FF. 9R-I 2V)}

Como se observa en el epígrafe, la estructura del primer capítulo sigue los pasos establecidos en la alabanza de lugares. Quevedo se apoya en el epítome que el historiador romano Justino hizo en los siglos II o III de las Historias filipicas de Pompeyo Trogo; en concreto, traduce con cierta libertad parte del primer capítulo del libro XLIV. Junto a esta fuente, Quevedo indica también su deuda con la geografía de Estrabón en lo referente a la forma de la península ${ }^{34}$.

En este capítulo, el recurso argumentativo más importante es, con mucho, el uso de autoridades. Otros dos destacan junto a él. Uno de ellos es la comparación que hace a España superior a las naciones extranjeras, cuya importancia

relación entre Quevedo y Mariana en Jauralde, 1995, y, 1998, pp. 248-256.

32. Girolamo Benzoni, Historia del mondo nuovo..., Venezia, 1565. Selden Rose, 1916, p. 25, nota 2, indica que Quevedo debió de ver la edición francesa de 1579, a juzgar por la semejanza en el título que ofrece.

33. Los epígrafes se irán señalando a lo largo del trabajo. Puede compararse su semejanza con los rasgos que la retórica adjudicaba a estos elogios en Quintiliano (Institutio Oratoria 3, 7, 2627) y Hermógenes (Progymnasmata 7).

34. Para las deudas de Quevedo en este capítulo, véanse Jauralde, 1997, 51-52, 1998, p. 213, y Roncero, 2000, pp. 45-47 y 76. 
resulta lógica en una patriótica defensa contra los ataques foráneos. El otro procedimiento deriva del carácter panegírico del escrito, que hace esperable la acumulación de virtudes y méritos de la nación. España defendida ofrecerá frecuentes ejemplos de ello, en especial cuando Quevedo haga acopio de las excelencias de las letras y saberes hispanos. Un paso más se da cuando el escritor rehúsa referir dichas cualidades por ser su número tal que desbordaría sus fuerzas o los límites del escrito ${ }^{35}$. Sucede esto en un par de ocasiones dentro del capítulo primero:

Esto dize de Espańa, no español hijo apasionado, sino Justino de Trogo Pompeo, $\mathrm{i}$ añade tantas alauanzas de la pazienzia, fortaleza, zufrimiento i magnanimidad de sus hijos, que, por no hazer largo el capitulo, dejo de referirlas (p. 27, ff. 10v-11r).

No refiero las grandezas de todas tres coronas, Aragon i Portugal i Castilla, espezificamente, porque de todas en comun se dize con el nombre despaña (p. 28, f. 12r).

El capítulo ofrece otros recursos argumentativos de interés. Uno de ellos aparece en un pasaje -también tomado del epítome de Justino- donde se ponderan las cualidades del suelo y los habitantes de Galicia (ff. 11r-11v). Como es sabido, dicha zona no era demasiado estimada en el tiempo de Quevedo ${ }^{36}$, quien, de esta forma, utiliza la alabanza de Justino por dos razones: por un lado, porque la opinión del historiador romano contrasta con el desprecio de los propios españoles, uno de los motivos de queja que se reiteran en la obra; por otro, porque a través de esa referencia puede construirse un sencillo y eficaz argumento de menos a más (locus a minore ad maius) ${ }^{37}$ : al cantar las excelencias de la más desfavorecida zona de España, se suponen aún mayores las de sus otras partes.

\section{Capítulo Segundo: «Antiguedad de Spaña, i estima açerca de los ESTRANJEROS I ANTIGUOS SCRITORES» (FF. I 5R-28R)}

La antigüedad de sus fundadores es otro de los rasgos clásicos en los elogios de países, ciudades y lugares. Es también un topos en el que la verdad que se presupone a la historiografía deja paso a menudo a la fantasía de las leyendas,

35. Es una de las distintas manifestaciones de la denominada «tópica de lo indecible», muy presente en los panegíricos; sobre ella puede verse Curtius, 1981, pp. 231-235. Desde el punto de vista de la elocutio, este procedimiento se vincula a la preterición (praeteritio), figura que consiste en afirmar que van a omitirse ciertos aspectos que podrían tratarse con mayor detalle. Esa omisión consciente puede deberse a que no interesa profundizar en ellos; pero en otros casos, como este, la intención es precisamente subrayar su fuerza al afirmar que se obvian precisamente por su magnitud; véase Lausberg, 1960, $\$ \$ 882-885$.

36. Véase Herrero García, 1966, pp. 213-216.

37. El locus a minore ad maius es un argumento inductivo que prueba lo mayor partiendo de lo menor. Para incrementar su fuerza probatoria, es habitual colocar como minus un término de elevada connotación positiva o -como en este caso- negativa, para así subrayar la fuerza del que lo supera. 
donde el origen de los fundadores y reyes se retrotraía en el tiempo. Desde la antigüedad, griegos y romanos les buscaron un pasado mítico; los cristianos lo vincularon a las Escrituras, recurriendo sobre todo a la descendencia de Noé y a la confusión de lenguas tras la edificación de la torre de Babel. La historiografía hispana no escapó a esa tendencia, y desde la Edad Media proliferaron las listas de reyes de dudosa existencia. En el Renacimiento puede destacarse la influencia que en este sentido tuvieron las obras de los italianos Annio de Viterbo y Lucio Marineo Sículo, y la del español Florián de Ocampo ${ }^{38}$.

En este capítulo, Quevedo pretende desmontar la creencia en diversos reyes míticos de España, labor en la que ya le habían precedido plumas como las de Juan Luis Vives, Melchor Cano, Antonio Agustín y, en algunos casos, Juan de Mariana $^{39}$. Presidido por esa intención, el capítulo comienza exponiendo el principio general que guiará el intento quevediano: la antiquitas ha sido refugio de fantasías y mentiras sobre el origen noble de diversos pueblos y naciones:

Ai algunos que, asi a su nobleza como a su ser, acojiendose a la antiguedad, lo engrandezen i aumentan; i ciudades de los tiempos apartados hazen en si i en sus cosas todo lo que les falta, confundiendolo con los dias, pues queda burlada qualquiera dilijençia que pretende examinar cosa que huio a sagrado, donde no alcanza la memoria (p. 28, f. 15r).

A partir de ahí, el texto se organiza en dos grandes secciones. En la primera se tratan los falsos orígenes antiguos propuestos para naciones extranjeras. Destaca aquí la leyenda de Rómulo y Remo como fundadores de Roma y la afirmación de que su madre era una loba ${ }^{40}$. La refutación de Quevedo se argumenta mediante dos recursos que serán básicos a lo largo de España defendida: la erudición que aportan las auctoritates y la digresión que se extiende en el examen de diversas etimologías sobre el nombre Roma y su supuesta derivación de Rómulo; recuérdese, en este sentido, que uno de los habituales procedimientos para las

38. Annio de Viterbo, Commentaria super opera diversorum auctorum de antiquitatibus loquentium; eiusdem chronographia etrusca et italica, Roma, Eucharius Silber, 1498; el libro dedicado a Hispania se titula De primis temporibus et quatuor ac viginti regibus Hispaniae et eius antiquitate; Sánchez Alonso, 1941, vol. 1, pp. 356 y 369-370, señala su negativa influencia al aumentar la lista de reyes fabulosos iniciada por Túbal. Lucio Marineo Sículo, Opus de rebus Hispaniae memorabilius, Alcalá de Henares, Miguel de Eguía, 1530. Florián de Ocampo, Los cinco libros primeros de la Crónica General de España, Zamora, Juan Picardo, 1543 (continuada en 1573 por Ambrosio de Morales). Véanse también Sánchez Alonso, 1941, vol. 1, pp. 375-377, y vol. 2, pp. 13-18; Cirot, 1905, pp. 66-71, 81 y 97-147.

39. No me detendré en consideraciones sobre las fuentes manejadas y refutadas por Quevedo. Para estas cuestiones, véase Roncero, 1999a y 2000, pp. 89-119. Un panorama de la historiografía de los siglos XVI y XVII en relación con el auge de los falsos cronicones ofrece Godoy Alcántara, 1868, cap. VI, pp. 252-304.

40. Roncero, 2000, p. 105, señala el uso fragmentado que Quevedo hace de un pasaje de Tito Livio, omitiendo al principio la explicación de que era una cortesana, como indica después acudiendo a una cita de los Fasti $(3,12)$ de Ovidio: sacra lauaturas mane petebat aquas. 
propuestas de reyes y fundadores era inventar sus nombres a partir del que tenían los lugares cuyo origen se examinaba ${ }^{41}$.

La segunda sección, más extensa, se dedica a revisar diversas teorías sobre la fundación y los antiguos reyes de España. Quevedo se detiene en los casos de Gargaris y Habido, Gerión y Túbal, cuya existencia discute apoyándose en la crítica a las explicaciones etimológicas de sus nombres. Como será habitual en la obra, un aparato de autoridades acompaña sus razonamientos. Para desautorizar las falsas etimologías de reyes y fundadores inventadas a partir de nombres de lugares, Quevedo las reduce al absurdo al deducir a partir de casos como los de Túbal o Noé otros disparatados ${ }^{42}$; señalo el primero de ellos:

Con estos disparates dan lisenzia a las conjeturas para afirmar que Noe vino despues a Espańa, porque ai vn lugar que se llama Noela en Galizia, i otro que se llama Noega en Asturias. Segirse ia aquí que Odom, vna triste i moderna aldea tres leguas de Madrid, tiene el nombre hebreo, i que la fundo Adam, porque Adam hebreo, en siriaco muda, el camez en holem, i dize i se escriue 0 0 ' Odom; i con la misma lengua hebrea i sira se provara esta conjetura aun mejor que las de Tubal i Noe, porque dizen que por eso el primer padre se llamo Adam, porque fue hecho de tierra rubia, la qual en hebreo se llama Adama o Adam, que en siriaco primitivo es Odoma v Odom $\mathrm{i}$ es la tierra roja toda la de este lugar vezino de Alcorcon (p. 32, ff. 21v-22v).

Tras acumular algunas absurdas conjeturas al hilo de Túbal, vuelve a tratarse del rey Gerión. Ya se ha indicado que lo que conservamos de España defendida es un texto inacabado. En ocasiones su estructura muestra cierto desorden, imputable a ese hecho y a la acumulación de digresiones que hacen difícil seguir el hilo del razonamiento principal. Este segundo pasaje dedicado a Gerión parece algo desubicado, y obliga a Quevedo a hacer un par de referencias anafóricas a ideas que ya había expresado cuando se había ocupado de este rey con anterioridad ${ }^{43}$.

El texto prosigue por el camino de la acumulación y el rechazo de falsas hipótesis sobre el origen y fundadores de España ${ }^{44}$. El final de este capítulo debe

41. Sánchez Alonso, 1941, vol. 1, p. 362, constata el frecuente uso de la etimología toponímica en la historiografía hispana.

42. Quevedo censuró los excesos de las etimologías en otras obras suyas como en la carta a Alonso Messía de Leyva que encabeza el Cuento de cuentos: «En el origen della han hablado algunos linajudos de vocablos, que desentierran los huesos a las voces, cosa más entretenida que demostrada, y dicen que averiguan lo que inventan» (pp. 37-38). Ya Quintiliano, Institutio Oratoria, I, 6, 3-27, había señalado que la etimología era una investigación a menudo inclinada a razonamientos fantasiosos.

43. Estas consideraciones sobre Gerión se colocan aquí porque es un rey admitido por Beroso, y este era la fuente de los historiadores que aceptaban a Túbal, rey de quien Quevedo acababa de hablar. Aun así, la estructura del capítulo habría quedado más equibrada integrando estos datos en el lugar que antes se dedicó a Gerión de manera específica y, si acaso, haciendo ahora una leve mención recordatoria.

44. Aparecen de nuevo las citas de autoridades, como el pasaje del Satiricon 118 de Petronio donde, hablando de la correcta combinación de componentes literarios en autores como Homero 
situarse en esa acumulación que finaliza en el folio $27 \mathrm{v}$. Los folios siguientes muestran un rasgo característico de toda la obra; así, el folio $28 \mathrm{r}$ contiene el siguiente texto:

† mas claramente confirma por dudoso este orijen de los romanos i por fabula Aeliano lib. XIIII Variae Historiae cap. 36. titulo quod ridicule façiant qui propter maiores virtutem altum sapiunt, que son ridiculos los que se ensoberbezen i presumen por la uirtud de sus antepasados. Ettc-

-.---- si quidem in Marii patrem ignoramus quem tamen ipsum ob rerum gestarum macnitudinem suspicimus, item Catonem, Servilium, Hostilium et Romulum (p. 35, f. 28r).

Este texto no constituye el final del capítulo segundo, sino que es una anotación que, mediante una cruz, remite al folio $15 \mathrm{v}$, donde debería incorporarse como una nueva autoridad en la refutación de los orígenes fabulosos de Roma ${ }^{45}$. A esa nota le siguen varios folios en blanco (ff. 28v-31), cuyo espacio también se habría destinado a incorporar notas y ańadidos. Se constata, pues, la dificultad de delimitar una estructura definitiva de la obra por encontrarse aún en proceso de revisión.

\section{Capítulo tercero: «Del nombre de Spaña i su orijen i ETHIMOLOGIA» (FF. 32R-5IV)}

La base de su estructura es la acumulación (congeries) de autores y teorías sobre el nombre de España, a los que añade Quevedo sus propios matices y refutaciones. El análisis se centra en dos nombres: «Hispania» e «Iberia».

Esta serie de propuestas va precedida de dos afirmaciones que avanzan la intención de Quevedo. La primera de ellas justifica el hecho de dedicar todo un capítulo a esta cuestión. Quevedo debe demostrar que no se contradice en el descrédito hacia las etimologías que había manifestado en el capítulo precedente ${ }^{46}$. Por ello, afirma que no es su confianza en ellas la que le mueve a indagar en los orígenes del nombre de España, sino el hecho de que la gran variedad de hipótesis es un testimonio más de su grandeza:

No porque commigo puedan algo las etymolojias, que las mas vezes son obra del injenio, i no testimonios de la berdad, gasto en la razon del nombre

\footnotetext{
y Virgilio, se menciona la curiosa felicitas de Horacio. Quevedo usa aquí la cita irónicamente para criticar el hallazgo etimológico de fray Domingo de Baltanás, dominico que vivió entre 1488 y 1567 y escribió un Compendio de algunas cosas notables de España; la propuesta en concreto deriva «Elvira» de "Iberia». El lugar de Petronio es, por otra parte, bastante citado; encabeza, por ejemplo, los preliminares de González de Salas al Sermón estoico y la Epistola satírica y censoria (véase Rey, 1999, p. 319). La siguiente frase muestra ese afán por acumular datos que, en ocasiones, dificulta el logro de una estructura proporcionada en los capítulos: «i porque no quede nada por aduertir en lo que importare al desengańo del Beroso...» (p. 34, f. 26v).

45. Así lo indicó ya Roncero, 1997, p. 218, quien incorpora la anotación al folio 15v en su edición de 2012. El trazo más fino de la pluma en esta parte corrobora que la nota fue copiada por Quevedo en un momento posterior a la redacción del capítulo.

46. Véase lo dicho en la nota 42.
} 
despaña este capitulo, solo porque en el origen vario dél se le recompensa mucha de la antigüedad que en el capitulo pasado no e admitido, por mal deduzida de los sueños de Anio (p. 36, f. 32r).

Desmarcándose de aventuradas propuestas etimológicas, Quevedo adopta el papel no solo de compilador de las muchas existentes, sino de juez que examina su verdad, en una línea semejante a la que antes mostró con los fundadores y primeros reyes. Ese afán de rigor y verdad ante los historiadores anteriores -que es, en cierta medida, un tópico de la historiografía ${ }^{47}$ - sirve a Quevedo para contrastarlo con la actitud de las naciones extranjeras, que se contentan con panegíricos falsos y sin fundamento.

Con esas declaraciones de principios, el capítulo discurre como una suma de propuestas sobre los nombres «Hispania» e «Iberia». Todas ellas se acompañan de la opinión de Quevedo, quien concederá menor fiabilidad a las que más se acercan a los territorios de la conjetura etimológica y los orígenes legendarios, ya desmentidos en el capítulo anterior.

En ese examen, el rechazo de algunas propuestas se fundamenta en el recurso al análisis filológico. De censor de falsos historiadores, Quevedo pasa a fustigar a los críticos que deturpan los textos al modificarlos con conjeturas mal fundamentadas que los adecuan a sus intereses. Destaca en este sentido el examen de dos loci critici ${ }^{48}$. En el primero de ellos, referido a los orígenes de Hispania, analiza el error que el portugués Nonio achacó a Ortelio ${ }^{49}$ por no haber corregido la lectura $\pi \alpha v v \omega v i \alpha$ (Pannonia) que, según Nonio, debía leerse $\pi \alpha v i \alpha$ (Pania). Para Quevedo, el texto griego debía haber leído $\pi \alpha v \omega v \alpha$ (Panona), derivado de Pan, por lo que el error en la edición de Ortelio habría consistido en añadir una $v$ y una 1 (Panona-Pannonia). Prefiere esta conjetura a la voz $\pi \alpha v i \alpha$ (Pania) propuesta por Nonio, y desde la que Quevedo cree que se explica con más dificultad el error Pannonia ${ }^{50}$ :

No me pareze que fue grande el hierro que se le escondio a Hortelio en pasar

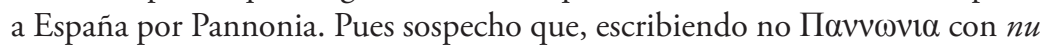

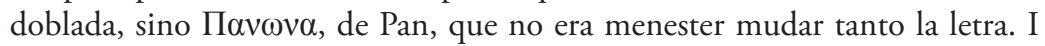
estaua mejor deduzida de Pania, i mejor de Pana Panona (Orfeo, hymno de Pan, dize en el postrer uerso semejante deriuatiuo: Пavikov, Panicon). I tengo por mejor i mas acomodada mi conjetura, i por disculpado a Ortelio, pues fue solo perdonar dos letras al impresor, vna $n$ duplicada i una $i$ (p. 37, f. 34v).

47. Véase, para la historiografía hispana, Sánchez Alonso, 1941, vol. 1, p. 362.

48. A ellos cabe ańadir el siguiente pasaje, donde Quevedo utiliza dos gráficas metáforas para censurar la intervención sobre los textos: «Dize luego, i concuerda bien Juan Anio quando dize que del rrey Beto se dize Betica; quiza, mudando poco del rey, leieron rio los criticos, que mas son despedazadores de libros i roedores de palabras» (p. 42, f. 45r).

49. Petrus Nonius (1502-1578) fue un destacado matemático y cosmógrafo portugués. Abraham Ortelio (1527-1598) fue un cartógrafo y geógrafo flamenco, famoso por su Theatrum Orbis Terrarum, publicado en Amberes en 1570 y que conoció múltiples ediciones.

50. Bernardo de Aldrete había dedicado el libro III, capítulo II de su obra Del origen y principio de la lengua castellana... (1606) al origen de los nombres de Espańa; allí mencionaba también este pasaje, para el que aceptaba la voz Pania y rechazaba como error Pannonia. 
En el segundo pasaje, Quevedo censura a Nonio y a Isaac Casaubon el haber corregido la lectura de Estrabón, que llamaba «igletas» a los habitantes de la península. Ambos proponen la lectura "gletas», ante la cual Quevedo manifiesta su recelo por las conjeturas que modifican sin base los textos y, en lugar de intentar agotar el sentido de un pasaje o voz oscuros, prefieren alterarlos y explicar ese cambio creando una hipótesis ad hoc:

Strabon, al fin del lib. iii, llama a los auitadores despaña igletas. No halla

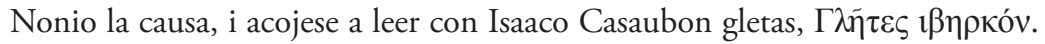
Quiere dezir pueblo de Spaña, en los cynetas, que, segun Stephano, eran junto al Oçeano, junto a las columnas de Hercules, de donde se dijo Cynetico promontorio. No me contenta este modo de dar luz a los libros, leer vno por otro, pues es no entender el autor, sino hazerle dezir a su pesar lo que no quiere. I aunque en algunas cosas sea bueno, con exemplares de otra suerte es huir la dificultad i leuantar testimonios a los autores (pp. 37-38, ff. 34v-35r).

Sin embargo, no es esta la línea de argumentación más destacada. Junto a la mencionada acumulación de autores y teorías, serán el raciocinio y la cita de autoridades los procedimientos fundamentales en este capítulo. Ambos se combinan en el siguiente pasaje, destinado a rechazar las hipótesis que hacían derivar de ríos los nombres de países:

I si al Nilo llaman negro por la negra tierra que trai, i la de Ejipto es negra, o por serlo o por fertil, que a la que lo era llamavan asi los griegos (vease en Anacreon), claro es que el rio tomo el nombre de la tierra, i no Ejipto del rio. Esto confirma Heliodoro en sus Amantes, en su segundo libro, oraculo: «o tu, estranjero, que la fertil tierra que el grande Nilo riega vas dejando, pensando huyr el hado inevitable, ten corazon y zufre, que muii presto veras de Ejipto los morenos campos!», con que se ue que eran negros por fertiles i por negros (p. 42, f. 44r).

De nuevo resulta difícil delimitar el final del capítulo. Tras una serie de consideraciones y autoridades sobre los nombres «Hispania» e «Iberia» (f. 48v), el folio 49r recoge una anotación que interrumpe el texto. Esa nota remite, mediante un triángulo, al folio 39r, donde habría de incorporarse como una precisión a Bernardo de Aldrete ${ }^{51}$. Como ya había sucedido al final del capítulo II, también aquí el trazo más fino de la pluma denota que ese texto fue escrito en un momento diferente. El capítulo continúa en el folio $49 \mathrm{v}$ con diversas precisiones sobre una cita de Festo Avieno, autor que había sido mencionado en el folio 48v, justo antes de la anotación comentada. Como sucede en todos los casos, el cierre del capítulo lo constituyen unos folios en blanco (ff. 50-51) para futuros añadidos.

51. Véase el texto en la edición de Selden Rose, 1916, pp. 45-46, desde «Traslado todo esto Alderete» hasta «a San Pablo i a Hesichio». Roncero, 2012, refleja correctamente la ubicación de la nota quevediana. 


\section{Capítulo Cuarto: «De la lengua propia despaña, De la lengua}

ANTIGUA I DE LA DE AORA; LA RAZON DE SU GRAMATICA, SU PROPIEDAD, COPIA I DULZURA» (FF. 52R-I 5 IV)

La presencia de la lengua y las letras en los elogios de países y ciudades puede rastrearse desde antiguo, y se incorpora a la canónica alabanza de sus excelencias en el cultivo de las artes y las ciencias. El humanismo renacentista reforzó su importancia, hasta el punto de que los loores de las letras cobraron independencia como género ${ }^{52}$. Esa evolución se observa también en la tradición de las laudes Hispaniae donde, desde el mayor rango que se da a las gentes y sus actividades a partir de san Isidoro, se produce un paulatino crecimiento de la alabanza de las letras hasta convertirse en el centro de las laudes ${ }^{53}$.

Tal vez esa importancia de los loores de las letras y de la lengua sea una de las razones de que este capítulo sea el más extenso de España defendida, y también el más cuidado en su estructura. A ello debe ańadirse el interés de Quevedo en estas cuestiones ya que, según dice, preparaba un tratado sobre las grafías de las letras ${ }^{54}$. Con todo, si se considera la estructura global de la obra, es este un rasgo que muestra su evidente desproporción, pues la longitud de este capítulo contrasta con la de los demás, en especial con el quinto y el sexto. De nuevo se observa que nos hallamos ante un texto necesitado de una revisión que, en este punto, buscase un mayor equilibrio estructural ${ }^{55}$.

A modo de exordio, el capítulo se inicia con la explicación de las causas que movieron a Quevedo a escribirlo. Además del ya mencionado silencio de los españoles sobre sus propias excelencias, la razón fundamental será refutar al geógrafo holandés Gerardo Mercator, quien en su Menor Atlante había menospreciado la lengua de los espańoles ${ }^{56}$. Quevedo señala de forma explícita las dos grandes secciones de que constará este capítulo: la primera, una amplia información sobre la lengua de Espańa; la segunda, una respuesta detallada al geógrafo holandés ${ }^{57}$.

La primera sección se inicia con la preceptiva definición de lo que Quevedo considera «lengua propia despaña $»^{58}$ :

52. La bibliografía es abundantísima; para su reflejo en España, véanse, por ejemplo, Rico, 1978; Terracini, 1979; Carrera de la Red, 1988; Gómez Moreno, 1994, pp. 227-241.

53. Binotti, 1995, pp. 10-35.

54. «I aun si no fuera por no ser prolijo, provara quanta similitud tiene nuestro alfabeto con el alfabetho de los Rabies, hasta en las letras rasgadas, de que dare razon en el tratado que escrivo de la comun razon de las letras i lenguas" (España defendida, p. 54, ff. 66v-67r).

55. Lo había apuntado ya Jauralde, 1997, p. 47, 1998, pp. 209 y 214.

56. Más detalles en Jauralde, 1997, 52-55, 1998, pp. 214-215; véanse también las reflexiones de Schwartz, 2003, pp. 367-370 sobre este capítulo cuarto.

57. «A todo esto respondere palabra por palabra, en abiendo satisfecho con el titulo de mi capitulo a todas estas dudas» (p. 46, f.52v). Este tipo de párrafos que avanzan la estructura de un capítulo o sección ya fue comentado al analizar el preliminar «Ocasión y causas deste libro».

58. Véase la semejanza del pasaje con el siguiente que encabeza el Cuento de cuentos: «La habla que llamamos castellana y romance tiene por dueńos todas las naciones: los árabes, los hebreos, 
Llamo lengua propia despaña la que mesclaron con la suia los romanos, penos i moros; despues la propia de los españoles, de la qual pocas reliquias, sin rrazon despreziadas, apenas guarda la antiguedad, pues solas tenemos las que perdono el tiempo en algunos libros, i aun esas no sabemos si son çiertas (p. 47, ff. 53r-54r).

Esta definición resulta de gran importancia estructural, pues sirve de guía que avanza lo que serán los distintos apartados de esa sección. Así, Quevedo se ocupará primero de analizar las voces de la lengua propia de España, para luego abordar las que proceden de su contacto con las de otros pueblos ${ }^{59}$.

En las voces que se conservan de la lengua propia de España, Quevedo sigue a Bernardo de Aldrete ${ }^{60}$, deuda que se advierte de forma general en todo este capítulo. No obstante, su afán por aportar nuevos hallazgos le hace matizar de inmediato algunas de sus propuestas, aventurándose entonces en el terreno de la conjetura etimológica. También corrige a Gregorio López Madera, el gramático cuya hipótesis del castellano como una lengua con una base inmutable a los cambios se enfrentaba a la evolutiva de Aldrete. Sin embargo, en algunos pasajes destinados a ponderar la antigüedad del castellano parece acercarse a algunas de sus posturas ${ }^{61}$.

El párrafo que concluye el estudio de las voces propias tiene una doble finalidad: por un lado, enlaza con las futuras secciones que va a destinar a las voces que el español tomó de otras lenguas; además, es una alabanza de

los griegos. Los romanos naturalizaron con la vitoria tantas voces que la sucede lo que a la capa del pobre, que son tantos los remiendos que su principio se equivoca con ellos» (p. 37). Este pasaje del Cuento de cuentos precede al de las etimologías que fue citado en la nota 42.

59. Aldrete se ocupó de las voces propias en Del origen y principio de la lengua castellana (libro II, capítulos 4 y 5), y de las voces procedentes de otras lenguas en el libro III de la misma obra.

60. «i con variedad de dotrina a estremado la dificultad del orijen de nuestra lengua, que, por la mucha variedad de ella i de los idiomas que la hazen rica, fue casi el mismo trabajo que el del Nilo, el dotor Bernardo de Alderete de Cordova; i asi me remitire a el en lo demás [tachado] el en gran parte de mi intento" (p. 47, f. 53v). A esta afirmación siguen unas líneas tachadas en el manuscrito, donde Quevedo dice haber tenido en cuenta también un libro no impreso del doctor Rosal: «aunque aun [tachado] su libro i a mi capitulo serbira sera de importanzia el ethimologico del dotor rosal que me impropiamente invidiosamente intitula origen de la lengua castellana obra de varia dotrina y no dada a la estampa por falta de conozimiento en los libreros i de hazienda en el autor» (f. 53v). Se refiere al Origen y etymología de todos los vocablos originales de la lengua castellana, del médico cordobés Francisco del Rosal (h. 1560-1610); véase Bussell Thompson, 1975, pp. 3-15. Roncero, 1997, p. 217, indica que quizás la defectuosa sintaxis del pasaje fue la causa de su supresión.

61. No resulta del todo clara la posición de Quevedo en relación con estas dos teorías. Comparte -y así lo declara- buena parte de los planteamientos evolutivos de Aldrete, y refuta explícitamente en varias ocasiones a López Madera. No obstante, al afirmar que el castellano tiene más antigüedad que el latín y el griego (pp. 34 y ss.) parece acercarse a algunas posiciones de este último, las cuales resultaban muy adecuadas para ponderar la dignidad y antigüedad del castellano y, con ello, de España. Más difícil aún es precisar si ese eclecticismo deriva de la reflexión sobre el sistema de la lengua, o de la práctica argumentativa que extrae de cada doctrina lo más adecuado a sus intereses. Para la posición de Quevedo en esta polémica lingúística, véanse, entre otros, Binotti, 1995, pp. 118-123, y Sarmiento, 2002, p. 910. 
esa lengua propia de España. Dicha alabanza se sustenta en la antigüedad de esas pocas palabras (reliquias) que conserva, en la elegancia de su gramática y sintaxis semejantes a la hebrea y, lo que resulta argumentativamente más interesante, incluso en las voces que luego incorporó de otros pueblos; ese rasgo, que podría desvirtuar la pureza de la primitiva lengua española, se torna aquí virtud, pues aporta abundancia (copia) léxica al idioma. Quevedo muestra así cómo las teorías lingüísticas se supeditan en su escrito a la argumentación en defensa de su tesis:

esto es lo que io he podido aduertir azerca de las reliquias y lenguaje antiguo despaña, que tan çiegamente se len i con tanta dificultad se hallan, por estar çiegas con voces penas $i$ arabes $i$ romanas, ia naturalizadas con el uso y reziuidas de nuestra grammática, que es la propia hebrea en declinaziones de nombres $\mathrm{i}$ en conjugaziones de verbos, i por eso mas elegante que muchas, i mas copiosa por eso i por seruirse para su copia i propiedad de la lengua hebrea, de la arábiga, de la cartajinesa, de la latina i de la griega, como se conoce en todas sus vozes (p. 51, ff. 61r-61v).

La primera lengua que trata Quevedo es el hebreo ${ }^{62}$. Además de señalar algunos ejemplos de vocablos, insiste en dos aspectos fundamentales para emparentar con ella el castellano. Uno es la gramática: para Quevedo, la gramática española coincide con la del hebreo, pues, a diferencia de la griega y latina, no se declina. El otro es la forma de las letras, aspecto sobre el que afirma estar preparando un tratado. Estos dos rasgos proporcionan al castellano más antigüedad -y, por lo tanto, autoridad- que a las lenguas griega y latina. Es aquí donde su opinión se aparta más de los postulados evolutivos de Aldrete, pues prevalece el afán de la alabanza mediante la antiquitas.

En el repaso a las voces griegas, Quevedo actuará según la pauta que guía esta parte de su obra, es decir, añadir algunos datos a los ya expuestos por Aldrete sin ofrecer un análisis detallado. Así, señala aquellas voces griegas que Aldrete olvidó y sí recogió el helenista del XVI Francisco de Vergara. A ellas añadirá algunas de su propia cosecha; el párrafo con que las introduce es toda una declaración de intenciones sobre el afán de novedad y erudición que persigue, actitud de la que ya se han señalado otros ejemplos:

I porque no parezca que juntamos o amontonamos como otros, es menester ańadir algo del propio estudio, aunque poco, por no hazer maior el volumen con lo escusado (p. 56, ff. 69v-70r).

Respetando el orden que se avanzó al comienzo del capítulo, sigue un breve repaso por las huellas que las voces árabes dejaron en castellano. Se centra luego en las cartaginesas, aspecto que merece más el interés de Quevedo porque le permite subrayar la novedad de sus aportaciones. Quevedo pretende así situarse al nivel de humanistas consagrados como José Justo Escalígero o Isaac

62. Para más detalles sobre aspectos lingüísticos referidos a Quevedo y su dominio del hebreo, véanse Caminero, 1979, Pascual Recuero, 1982, y Roncero, 2000, pp. 26 y 61-67. 
Casaubón, que no se adentraron en este camino que él pretende transitar en su análisis de un pasaje del Peno de Plauto ${ }^{63}$. Sin entrar en juicios comparativos sobre el nivel de erudición de unos y otros, interesa aquí señalar el uso de esos ilustres humanistas como auctoritates que avalan el comentario erudito de Quevedo. Este les rinde a ambos la lógica pleitesía para, de esta forma, sobrepujar su propio intento ${ }^{64}$ :

Desta lengua pena aun ruinas no an quedado; solo escondio Plauto al tiempo i a la antiguedad en el Penulo vnas pocas, las quales hasta oi no an sido tocadas de comentador alguno. Solo Scalijero el hijo, vanaglorioso, amenazo las jentes com promesas de esa auentura, i despues de su muerte Frederico Taubmano ${ }^{65}$, adulando a Isaaco Casaubon, dize que a el le aguarda esa zifra nunca entendida. I creo, según los dos son doctos, tubiera claridad esta duda, a aber merezido su cuiidado, que justamente poseen hombres maiores (p. 58, ff. $72 \mathrm{v}-73 \mathrm{r}$ ).

En ese repaso a las lenguas que han aportado voces al castellano, la última sección es, lógicamente, la dedicada a las voces romanas, pues es la más reciente y la que más huellas ha dejado. Se organiza como una acumulación de los distintos tipos que señala Quevedo al comienzo: «Pierdense vnas bozes, i otras se corrompen, y otras se conservan» (p. 61, f. 78r). Sobre esa pauta va mostrando su idea de la evolución de la lengua al recoger no solo casos evidentes sino, como hace en otras ocasiones, al matizar o corregir los que considera errores de interpretación.

Al tratar de las huellas del latín en el castellano, Quevedo se enfrenta en varias ocasiones a las teorías de Gregorio López Madera ${ }^{66}$. Para este gramático, el castellano primitivo sería una lengua anterior al latín y habría mantenido su

63. Escalígero, Casaubón y el propio Peno de Plauto son referentes de máxima dificultad y erudición que, desde un ángulo paródico, Quevedo usó en La culta latiniparla (pp. 98 y 102) para satirizar la oscuridad del estilo culto.

64. Pueden encontrarse juicios distintos sobre esta cuestión en Jauralde, 1998, p. 219, y Roncero, 2000, p. 80-82. Dejando a un lado la mayor o menor capacidad de Quevedo para igualarse a estos autores, es evidente que su obra filológica no es comparable a los monumentos de los mencionados humanistas. Pero también debe tenerse en cuenta que España defendida no es un tratado, sino el texto inacabado de un panegírico construido sobre las técnicas de la alabanza y la refutatio.

65. Friedrich Taubmann (1565-1613) fue un destacado poeta neolatino y filólogo que enseñó en la universidad de Wittenberg; destacó por sus ediciones y comentarios de autores clásicos como Virgilio.

66. Las observaciones contrarias a las hipótesis lingüísticas de López Madera no impiden que Quevedo alabase su figura en otros contextos. Así, en Grandes anales de quince días (pp. 9193) ponderó su labor como alcalde de corte en las diligencias que investigaron las actividades de Rodrigo Calderón. También concordó con los planteamientos de su obra Excelencias de la Monarchía y Reyno de España (1597), que se asemeja a España defendida en la configuración de sus capítulos III, X y XI, donde López Madera, en la tradición de las laudes, habla de la antigüedad y fundadores del reino de España, de la antigüedad de su nombre, de su grandeza y riquezas y de las de sus súbditos. 
esencia incorruptible ${ }^{67}$. Las discrepancias con López Madera ofrecen buenos ejemplos de técnicas refutadoras, de las que aquí se señalarán los casos más destacados.

Al refutar a López Madera, Quevedo cita en varias ocasiones pasajes del libro XII del Fuero Juzgo de Toledo, texto legal visigodo que dicho gramático había manejado como apoyo de sus propuestas ${ }^{68}$. En el siguiente pasaje, Quevedo combina el silogismo con un recurso muy habitual en las refutaciones: fragmentar una cita en beneficio de su propia hipótesis. Así, comienza citando un pasaje del fuero que contiene voces castellanas semejantes a las usadas en el siglo XVII; sobre ese texto construye el esperable razonamiento que llevaría a concluir, con López Madera, que entonces se hablaba la misma lengua castellana. Finalmente, esa conclusión se desmonta al continuar la cita del fuero, pasaje este donde sí aparecen numerosas voces castellanas perdidas en tiempo de Quevedo:

es fuerza que hablasen los menos distantes de su imperio en Espańa menos corrupta la lengua latina, i mas los que aora hablamos, como se ue por todos los Fueros Juzgos i escrituras antiquissimas, donde hasta lo que aora damos articulo femenino le tienen al rebes, i vozes de pueblos i lugares no conozidos, $i$ asta los apellidos fueron otros, como se ue en el Fuero Juzgo de Toledo, que ia cite arriba, lib. 12, titulo de los judios que venden los siervos christianos o que los franquean: «A los muii sanctos e muii bienabenturados don Agapio e don Ceçilio, e a los juezes e a los obispos de aquel lugar, e otrosi a los otros saçerdotes de aquella tierra.» Digo io colijirse ia bien que, porque este pedazo esta escrito en el propio lenguaje que aora ablamos, que aora quatrozientos i siete años que a que se escribio este Fuero Juzgo, se hablaba la propia lengua de aora, siendo lo que se sige en este tenor claro argumento contra la mayor fuerza que haze Gregorio Lopez Madera en su Monte Santo con vn retazo de vn previlejio. Prosige asi el capitulo propuesto: «de aquella tierra de Barbi i de Sturgi i de Yliturgi, e de Macia e de Thuga, e de Thartugi, e de Agabia, e de Apegro, que son en esas tierras, salut», nombres no conozidos son a nuestra lengua. Non, dezian, i ahora no; i podie, fiziemos; cuemo dezian, no como; i sos, no sus; seer no ser; otri no otre [...] Las vozes eran muchas diferentes: buena era hazienda, aora bienes (pp. 61-62, ff. 79r-81r).

La acumulación de voces y referencias al Fuero Juzgo termina desautorizando la hipótesis de López Madera ${ }^{69}$ y añadiendo una observación de Quevedo donde

67. Esa hipótesis se desarrolla en sus Discursos de la certidumbre de las reliquias descubiertas en Granada desde el año de 1588 (Granada, 1601), también conocido como Discurso del Monte Santo de Granada, obra donde López Madera defiende la autenticidad de las reliquias conocidas como los plomos de Sacromonte; véase, Binotti, 1995, pp. 36-63, donde se hallan más referencias bibliográficas.

68. Véanse más detalles sobre el Fuero Juzgo en las hipótesis de López Madera y Aldrete en Nieto Jiménez, 1975, pp. 149-155.

69. «Asi que, siendo tanta con los dias la mudanza de las lenguas, que aier dezian en Espańa buestra señoria, i luego dijeron bueseñoria i luego buesia i aora busa, i toda esta mudanza e alcanzado io en la corte en menos de veinte ańos, mal haze quien procura defender que desdel tiempo de Nuestra Señora se hablaba asi como aora, si apenas vocablo antiguo se conoze ia en las vozes castellanas, no digo vocablo propio de la lengua, porque eso vese con toda zerteza que 
remite a Aldrete para más consideraciones sobre dicho texto legal ${ }^{70}$, pues este gramático ya había rebatido las hipótesis que utilizaban el Fuero Juzgo como un aval para la teoría del castellano primitivo en su obra Del origen y principio de la lengua castellana... (libro III, capítulo II).

Cuando un autor recurre a la cita de una autoridad para avalar sus ideas, es habitual que se le refute con una interpretación distinta de la fuente. La cita reproduce un fragmento de texto, por lo que la refutación puede a menudo desautorizarla aprovechando las líneas o versos que la preceden o siguen ${ }^{71}$. Así sucede cuando López Madera apoya sus ideas sobre el cambio lingüístico en una cita del Arte poética de Horacio, cuya interpretación rechaza Quevedo recurriendo a un contexto más amplio en el que apoya su distinta visión del pasaje horaciano. López Madera había citado los vv. 70-71 del Arte Poética interpretándolos como una alusión a un proceso evolutivo de las lenguas consistente en degradarse primero y luego volver a su original pureza. Quevedo lo rebate citando el pasaje completo de Horacio (vv. 68-71) y contextualizando su significado:

Dize luego [López Madera]: el sexto engaño i equivocazion es pensar que nuestra lengua tubo en sus prinzipios la barbarie i groseria que muestran algunas escrituras. Barbarie i groseria llama las vozes mas semejantes a su orijinal i menos ofendidas del pueblo. Adelante asi: la qual equivocazion consiste en no considerar que es muii çierto lo que dijo Orazio, que los lenguajes tienen sus mudanzas, de manera que se hablan en vn tiempo bien i en otro se corrompen i mudan, i despues buelben a su pureza primera, que es lo que el dijo: Multa renasçentur que iam çecidere, cadentque / Quae sunt in honore vocabula, si volet usus...

No pudo entenderse peor este lugar tan claro. Dise Orazio asi, en la satira postrera contra los malos poetas: Mortalia facta peribunt, / Necdum sermonum stet onos, et gratia vivax; I Multa renascentur quae iam çecidere; cadentque I Quae nunc sunt in honore vocabula, si volet usus, / Quem penes arbitrium est, et ius, et norma loquendi. [...] Esto Orazio, donde no trata de las lenguas, ni dize que la que en tiempo de Zizeron se hablo vien i aora se habla mal, se a de tornar a hablar tam bien como en el tiempo de Çiçeron, siendo fuerza que se hable perdida siempre peor; solo trata de la poca seguridad que tienen, si se les atreue el vso, las vozes mas hermosas, porque, en tomandolas el bulgo, el mismo Orazio las reprueva (pp. 65-66, ff. 87r-88r).

Una serie de consideraciones sobre el término romance se convierte en otra refutatio a algunas observaciones de López Madera. Se combinan en ella diversos procedimientos argumentativos. En el siguiente pasaje se comienza con

no ai ninguno oi en el vso. I querer dezir que nuestra lengua i la latina fue toda vna es lastimosa ignoranzia, pues desmiente a los mismos antiuos latinos que de mas çerca conozieron la uerdad i dijeron expresamente no solo que eran diferentes sino que en la suia admiraban la dureza de la nuestra. Autores i lugares a esto Alderete en su libro» (p. 63, ff. 83v-84r).

70. La observación dice: «autores i lugares, a esto Alderete en su libro» (p. 63, f. 84r). Roncero, 1997 , p. 220, interpreta esta frase como «un recordatorio para una futura revisión del libro».

71. Otros ejemplos quevedianos de este recurso se indican en Azaustre, 2000 y 2005. 
la fuerza de unas breves pullas e hipérboles burlescas propias de la invectiva ${ }^{72}$, para luego rebatir la idea con un silogismo que, finalmente, se ilustra con un ejemplo ${ }^{73}$ :

Así que Gregorio López Madera no entendio el lugar; i luego por vltima fuerza dize estas palabras: «y como llamaban romanos a los naturales, en consequenzia necesaria, a su lengua dezian romana.» Esto es otro disparate, porque llamar romanze asi nuestra lengua, es cosa moderna mas que piensa el dicho Gregorio Lopez. Prosigue asi: «pero nunca davan que se vbiese llamado latina, porque siempre fue idioma propio i distante del latin.» ¡Miren si lo emmendo! Aquí nos a cojido. Menester es vn adiuino etrusco para esto. Espantome que vn hombre tan onrrado dijese tal cosa, sin aduertir que, si los romanos eran latinos, i la lengua latina era la romana, que es lo mismo dezir lengua romana que lengua latina; latina se llama la de Roma, porque Roma la tomo en su fundazion del Latio para el imperio, i la misma se llama romana en España, tomada de Roma. Pongamos este caso: dos nombres tiene nuestra lengua: romanze i castellano; ¿no seria lo mismo dezir: ia los aragoneses hablan romanze, que dezir: ia los aragoneses hablan castellano? Pues lo mismo es en Espańa: hablan romanze o hablan latin, hablan lengua romana v lengua latina, siendo vna misma (pp. 64-65, ff. 86r-87r).

La refutación a López Madera se acerca a su final con un silogismo que pretende ofrecer una solución para el problema de la autenticidad de las reliquias encontradas en el monte granadino -los famosos plomos del Sacromonte ${ }^{74}$ sin recurrir a erróneas teorías lingüísticas. Quevedo adopta una solución de compromiso semejante a la de Bernardo de Aldrete; la veracidad de ese castellano primitivo similar al de entonces, y encontrado en unos pergaminos supuestamente tan antiguos, no era prueba de su esencia inmutable, sino de que Dios había concedido a quien los escribió el don de conocer la que sería lengua futura, pues también le había dado el de la profecía ${ }^{75}$ :

72. La desautorización de ideas contrarias presentándolas de forma exagerada como ininteligibles y, por lo tanto, necesitadas de traducción o interpretación, es rasgo que aparece en otras obras de Quevedo. Véase el siguiente pasaje referido al estilo culto, cuyos personajes recuerdan al adivino etrusco de España defendida: «Un papel suyo leímos ayer yo y un obispo armenio y dos gitanos y casi un astrólogo y medio doctor. Íbamos por él tan a escuras como si leyéramos simas, y nos hubimos de matar en un obstáculo y dos naufragantes que estaban al volver de la hoja. No bastó construirle ni estudiarle, y así le conjuramos» (La culta latiniparla, pp. 98-99).

73. Véanse otros casos de combinaciones de exempla y raciocinios en Azaustre, 2000, pp. 51-54.

74. Sobre esta falsificación, véanse Barros Aguilera, 2004, y Barros Aguilera y García-Arenal (eds.), 2006.

75. Aldrete ya había propuesto esa solución en Del origen y principio de la lengua castellana... (1606): «Contra nadie escriuo, a nadie contradigo, ni me opongo, solo procuro con verdad dezir mi sentimiento; Mas que descortesia seria juzgar, ò afirmar lo contrario. Porque a todos estimo, i reuerencio, i mas a las cosas sagradas, que por ellas a passado esto muchos años en silencio, i se sepultara en oluido, sino me obligara à manifestarlo lo que en esto deuo. Assi nadie me oponga dellas, que las cosas de los santos no se an de juzgar, por las reglas ordinarias, de que io escriuo, i trato: fuera dellas camina lo que es sobrenatural. Bien se compadece, que sea cierto, i verdadero 
I es lo mejor i mas çierto, si todo aquel volumen se hizo para defender las reliquias de Granada, dezir que, pues es milagro maior la çerteza de la profezia, que, quien entonzes supo las cosas que aora son, sabia el lenguaje, i para que fuese mas clara la profezia, i careziese de dificultad, o por la aspereza de la lengua fuese inutil, comunico Dios con el don de la profeçia el de la lengua; i con esto no sera nezesario esforzar la verdad con fabulas i sueños (p. 66, ff. $89 \mathrm{r}-89 \mathrm{v})$.

Lástima que la tendencia a la digresión y la acumulación de datos no permita concluir así esa refutatio y la prolongue con una lista de errores de López Madera que, si bien contribuyen al acopio erudito, desmerecen la equilibrada estructura de esta parte ${ }^{76}$.

Como ya se ha dicho, al comienzo de este capítulo Quevedo había señalado que surgía como una refutación a los escritos donde el geógrafo Gerardo Mercator había menospreciado la lengua de España. Por eso, tras haber dedicado una primera parte a rebatirlo mostrando la antigüedad y riqueza del castellano, se centra después en "responderle palabra por palabra». Este tipo de refutación no podía faltar en un escritor satírico como Quevedo, quien dio pruebas de su dominio en obras como sus memoriales por el patronato de Santiago, la Respuesta al padre Juan de Pineda o su Comento contra setenta y tres estancias que don Juan Ruiz de Alarcón ha escrito a las fiestas de los conciertos hechos con el principe de Gales y la señora infanta María.

Lógicamente, la organización de esta refutación se basa en el texto de Mercator que se citó al principio del capítulo. Aunque no vuelve a desgranar los pasajes del holandés -algo habitual en otras refutaciones suyas-, Quevedo le va respondiendo punto por punto y utiliza para ello diversos recursos de argumentación.

Así, a la afirmación de que «en las escuelas hablan de mejor gana español que latin, mezclando no pocas palabras de moros» (p. 46, ff. 52r-52v), responde Quevedo con un silogismo que vuelve esa misma idea contra su autor;

lo que io dixere, i aquello tambien lo sea, pues la mano poderosa del Señor no es limitada para hazer marauillas sobre toda nuestra capacidad. Que si los sanctos Apostolos, i a quien ellos ponian las manos, recibian el don de hablar diuersas lenguas, i profetizauan, del mismo poder es, i no mas dificultoso, darles las que auia en el mundo, i no sabian, que darles las que no auia, $\mathrm{i}$ auian en algun tiempo de ser» (libro I, capítulo I, p. 4). Más tarde reiteró el argumento en el libro II, capítulo XVIII de Varias antiguedades de España, Africa y otras provincias (1614): «El lenguage comun Español, no dize qual, si el de aquel tiempo, o el deste. Habla sin duda del que auia de ser en esta edad [...]. Interpretó pues la prophecia para los Principes, en cuio tiempo auia de salir a luz, i reuelarse, i en el lenguage comun, que en aquella sazon se auia de vsar. Fue esta vna como señal de la verdad de la prophecia, i de su cumplimiento escriuiendola en la lengua que no auia, porque quando la vuiesse se auia de manifestar. De lo que auia de ser cierto i presente, mostró la certidumbre de lo venidero, i que todo se cumpliria» (p. 298).

76. Véase el pasaje en las pp. 66-67 (ff. 89v-90r) de la edición manejada: «i con esto no sera nezesario esforzar la verdad con fabulas i sueños, como lo an sido todos los referidos, i mas el dezir que acabamiento es palabra propia del idioma español [...] i pone este exemplo caput, cabo». Parte de este texto (desde "Esto afirma» a «exemplo caput, cabo») fue añadido por Quevedo posteriormente, como indica el grosor del trazo y su diferente tonalidad. 
resumiéndolo, sería este: si Mercator habla mal del castellano, debería también hacerlo de todas las lenguas que, como se ha demostrado y él mismo afirma, lo integran. El silogismo se extiende porque algunas de sus premisas incluyen citas de autoridades:

Si la lengua castellana tiene casi todas las vozes griegas asi como los griegos las pronunziaron, $\mathrm{i}$ es toda latin en los idiomas diferentes solo casi en la pronunçiaçion, como valençiano, portuges i castellano, si tiene casi todas las vozes mas propias del hebreo, como azerca de los lugares nota Arias Montano sobre Josue, i de la lengua de Africa antigua que hablaban los penos lo mejor, i de la tiria suia, porque hablaban estas dos lenguas los penos, i por eso Plauto dize en el Poenulo: Quid huc [ad]venisti nos captatum miscdilips, / Bisulca lingua, quasi proserpens bestia. Bocio sobre los psalmos: Micdilips, tanquam mixtus lips, ad cartaginenses aludens, quos bilingues etiam vocat Virgilius, primo Eneidos: "Quipe domum timet ambiguan Tyriosque bilingues. / Bilingues quia Tyria et Africa lingua vtebantur»; bilingues, porque vsaban de dos lenguas, la africana y la tyria, de la arabiga, quitado el cansanzio i molestia, muchas vozes de que refiere parte Navarrete; asi que, o as de dezir, Jerardo Mercador, mal de todas las lenguas orijinales, o no le as de dezir de la española en quanto a las vozes i palabras, pues son las mismas que en sus orijinales (p. 67, ff. 90v-91v).

En otras ocasiones, Quevedo recurre a un dilemma que pretende dejar sin salida posible la censura de Mercator ${ }^{77}$. Así sucede cuando rechaza la acusación de que «españoles, de felizes injenio[s], infelizmente aprenden» (p. 46, f. 52r):

Dizes que somos de felizes injenios, pero que aprendemos infelizmente. ¿En que hallas la infeliçidad? porque en las obras no, que eso, i a fe, lo emos provado. Solo deue de ser en que, siendo escritas para enseñarte a ti i a otros erejes la uerdad de la fe, no consigen su efeto; i esa, mas es infelizidad tuia, que de los que aprenden. Si es por aprender tarde, es herror i locura, i imposible, porque eso contradizes con hazernos felizes de injenio. $\mathrm{Si}$ es porque no aprendemos cosas serias i de ueras, toca eso a vosotros, cuio prinzipal cuiidado en las vniversidades esta en la pronunziaçion i ortografia en questiones de nombre (pp. 70-71, ff. 99v-100r).

Pero el recurso más usado para rebatir al geógrafo holandés es la acumulación (congeries) de obras y autores hispanos que igualan e incluso exceden a los clásicos. La fuerza de la propia acumulación se acompaña de diversos recursos destinados a incrementar la vehemencia de los pasajes y mover así los afectos, como paralelismo, anáfora e interrogatio ${ }^{78}$ :

77. El dilemma es un argumento que rebate cualquiera de las dos opciones del contrario, cerrando todos los caminos a favor de la posición del autor. Véase la definición de fray Luis de Granada: «Es pues el dilema una oración en que se reprehende cualquiera de las dos cosas que concedieres» (Retórica Eclesiástica, 2, IX, 5). Cfr. también Cicerón, De inventione, 1, 29, 45, y Lausberg, 1960, \$393.

78. Más detalles sobre sus funciones retóricas y ejemplos en la prosa de Quevedo pueden encontrarse en Azaustre, 1996. Jauralde, 1997, p. 54, 1998, p. 216, ha subrayado el tono retórico que la obra adquiere en esta parte. Roncero, 1999b y 2012, apdo. I. II, se ocupa de las 
Pues dime, dejando las cosas grandes, ¿Quién tienes tu en ninguna lengua, entren griega, hebrea i latina y las buestras, todas ocupadas en seruir a la blasfemia, que teneis que comparar con la trajedia exemplar de Çelestina i con Lazarillo? ¿Dónde ai aquella propiedad, grazia i dulzura? ¿Qué nazion no los a echo tratables a su idioma, como a podido, hasta los turcos i moros? ¿Qué Orazio, ni Properzio, ni Tibulo, ni Cornelio Galo, exçed[i]o a Garzilaso i Boscan, que Terenzio a Torres Naharro, que Anacreonte iguala a Garzi Sanchez de Vadajoz, que Pitagoras i Phoçilides i Theognides i Caton latino no se dejan venzer de las coplas de don Jorje Manrrique nunca bastantemente admiradas de las jentes? ¿Que teneis que poner en comparazion con el diuino Castillejo? ¿Qué oponeis al doctissimo Juan de Mena, donde es gran negozio entenderle i difiçil imitarle, i exçederle imposible? ¿Qué es igual al cuiidado i lima de los versos de Hernando de Herrera, a la blandura i propiedad de Figeroa, a quien dio Italia lauro i nombre de diuino? (p. 69, ff. 95v-97r) ${ }^{79}$.

Quevedo salpica esas acumulaciones con el uso de la preterición, figura que consiste en manifestar la intención de omitir ciertas cosas que solo se nombran. Pero, como reconocían los tratadistas de retórica, ese simple nombrar las cosas -máxime si la enumeración se adorna estilísticamente- tiñe de ironía el recurso $y$, a la postre, refuerza la presencia de lo que supuestamente se quiere soslayar ${ }^{80}$ :

Dejote de rreferir con mayores encarezimientos, si lo son palabras que aun quedan a deuer alavanzas a los sujetos, los nombres de Christo de frai Luis de Leon, cuias obras en todas lenguas triumphan de buestra imbidia. Dejo a Francisco Arias, Ribadeneira i Malon, singulares i poderosos a onrrar vna lengua con sus escritos (p. 69, f. 95v).

La refutatio a Mercator termina con un pasaje que se apoya en las anteriores acumulaciones de autores y obras para construir nuevos argumentos. El primero de ellos se aproxima a la concessio, esto es, el reconocimiento de que, aunque alguna de las razones del contrario puede ser verdadera, se ve superada por argumentos propios de mayor peso. Quevedo ha dedicado más de diez folios del manuscrito a reunir un cúmulo de autores y obras hispanos; pues bien, ahora afirma que, aunque no los hubiese aducido, bastarían las hazañas de los españoles para superar a las naciones extranjeras ${ }^{81}$ :

I quando todo esto no vbiera, Jerardo, contra ti, i no tubieran historias copiosas i elegantes todos los reyes de Spańa, era para nosotros gloriosa respuesta que los españoles mas se prezian de hazer cosas dignas de ser escritas, que no de scriuir sueños o lo que otros hizieron (p. 73, ff. 104v-105r).

tradiciones, autores y géneros que menciona Quevedo.

79. A los nombres de Herrera y Figueroa, Quevedo añade en nota a la parte superior del folio 97 $r$ a Francisco de Aldana, poeta por quien mostró gran estima en varios lugares (véase Azaustre, 2003, p. 151, nota 85). Al margen de los juicios literarios que pueda exponer, a Quevedo le interesa sobre todo el efecto de la acumulación vehemente. Esta serie de acumulaciones son pasajes bastante comentados de España defendida; véase, por ejemplo, Roncero, 2000, pp. 18 y 21.

80. Lausberg, 1960, $\$ 884$, recoge ejemplos de diversas retóricas.

81. El valor es una de las virtudes hispanas subrayadas desde las primeras laudes; véase Binotti, 1995 , pp. 19 y 75. 
Esa idea le permite justificar una de las tradicionales lagunas que se achacaron a los españoles incluso desde las propias laudes Hispaniae: el carecer de una tradición de poetas que hubiesen cantado sus glorias. Quevedo justifica esa ausencia con una hipérbole de sus hechos de armas que bordea la tópica de lo indecible ${ }^{82}$ :

I en Espańa ai entrambas cosas, pues an sido los espańoles fama de si mismos, i el parezer que no ai mucho escrito de ellos, es el auer hecho tantas cosas dignas de ser escritos, que nunca las igualaran con alavanzas los virtuosos i doctos, ni con invidia los estrańos enemigos suios (p. 73, ff. 105r-105v).

De haber terminado así la refutatio a Mercator, el capítulo mostraría un notable equilibrio en su estructura. Sin embargo, a continuación Quevedo parece adentrarse en la comparación de la lengua española con otras extranjeras ${ }^{83}$. Ese intento, que se extiende de los folios $105 \mathrm{v}$ a $108 \mathrm{v}$, se convierte en la contestación a un texto donde Erasmo se burlaba de la abundancia de eses en espańol asociándola al silbo de las serpientes. Ello da pie a Quevedo a introducir una serie de reflexiones sobre la pronunciación de las letras, aspecto acerca del que ha dicho estar preparando un tratado. En esas consideraciones y citas de autoridades Quevedo defiende la nobleza de la letra ese, y refuta a Erasmo censurando la erre, propia de bestias y de borrachos como los alemanes ${ }^{84}$. El pasaje constituye una nueva digresión que desequilibra la estructura del conjunto.

Lo que sigue hasta el final del capítulo (folios 109r a 114v) es una acumulación de voces que Quevedo analiza explorando de nuevo el terreno de la etimología. Se trata de unas anotaciones que deben incorporarse a los folios anteriores donde se trató del parentesco del castellano con diversas lenguas, tal y como ya indicara Victoriano Roncero ${ }^{85}$. Analizando el manuscrito, se advierten diversas marcas que así lo indican. En primer lugar (folio 109r), una cruz que se corresponde con otra similar en la línea 10 del folio 63r, donde deben situarse esas observaciones sobre voces hebreas; posteriormente (folio 109v, línea 4), una cruz dentro de un círculo que se corresponde con otra marca similar en el folio 71r, y que afecta a observaciones sobre voces griegas; más abajo, en el mismo folio $109 \mathrm{v}$, línea 15 , un guión dentro de un rectángulo que remite al folio $77 \mathrm{r}$, y que se refiere a voces y consideraciones sobre el cartaginés; por último (folio 110v, línea 15), una flecha que tiene su correspondencia en el folio $77 \mathrm{v}$, donde concluiría la parte dedicada a las voces cartaginesas y se iniciaría

82. Esa justificación fue esgrimida con frecuencia por los historiadores hispanos; el propio Mariana indicaba en la dedicatoria a Felipe III de su Historia general de España, que esta era más abundante en hazañas que en escritores. Véanse otros ejemplos en Sánchez Alonso, 1941, vol. 2, pp. $44,66,170$.

83. «I la comparazion de la lengua espańola en escritos i autores, no la e hecho hasta aora, sino solo en la propia lengua, en la qual compite con la griega i latina, i de las bulgares no con otra sino con la franzesa, noble en escritores, que, en las buestras, del latin se sirben hasta los ofizios biles, por defecto de la propia» (pp. 73-74, ff. 105v-106r).

84. Sobre estos aspectos del pasaje trató Roncero, 2000, pp. 49-50.

85. Roncero, 1997, pp. 218-219. En su edición de 2012, Roncero incorpora a sus lugares pertinentes las anotaciones de los folios 109r-110r. 
la referente a las que provienen del latín. A partir del f. 112v, las anotaciones recogen diversas propuestas etimológicas encabezadas por una cita de Plutarco y apoyadas en los glosarios de Bonaventura Vulcanius y Iohannes Meursius. Los folios 115 a 121 están en blanco; como en los anteriores casos, se reserva un espacio al final del capítulo donde continuar esas anotaciones sobre voces de diversas lenguas ${ }^{86}$. Nuevamente nos hallamos ante materiales que deberían reordenarse en la versión final de la obra.

\section{Capítulo V: «De las costumbres Con QUe Nazio España I de las} ANTIGUAS» (FF. I 22R-I 35V)

Es mucho más breve que el anterior, y esa desproporción en la longitud de los capítulos es un rasgo de desequilibrio estructural que abunda en lo inacabado de la obra. Como se observa en su epígrafe, aborda una cuestión muy frecuente en la literatura política de la época y que, en cierta medida, es también común a la literatura satírica y moral de todos los tiempos como una manifestación concreta de la querella entre antiguos y modernos. Se muestra aquí la convivencia del Quevedo panegirista con el escritor satírico que lamenta la degeneración de las antiguas virtudes de España. Sobre este último aspecto, su prosa y poesía ofrecerán abundantes muestras en obras como Los sueños, Politica de Dios o poemas como la "Epístola satírica y censoria contra las costumbres presentes de los castellanos» ${ }^{87}$.

Este capítulo muestra una organización bastante bien trabada. El contraste de las antiguas y virtuosas costumbres con las presentes determina que su estructura general sea bimembre y antitética.

Se inicia con un exordio donde se vinculan las costumbres propias de España a las cualidades de su geografía, enlazando en cierta forma con las ideas expuestas en el primer capítulo ${ }^{88}$. Los pasajes que cierran y abren esta

86. En este caso son siete los folios que se dejan en blanco, más que en los capítulos anteriores, algo explicable si se tiene en cuenta la mayor extensión que Quevedo ha dedicado a este capítulo IV.

87. La anotación de Rey, 1999, pp. 347-364, a este poema muestra las coincidencias con este capítulo de España defendida. En una de las versiones primitivas, la del manuscrito Spanish 56 de la Houghton Library, Harvard, lleva la fecha de 1625. Con independencia de que España defendida sea copia inconclusa de una obra temprana de Quevedo, esa similitud muestra la constancia de sus preocupaciones políticas y morales. Véase el análisis que hace Roncero, 2000, pp. 30-36, sobre los diferentes aspectos ideológicos y de pensamiento de este capítulo V. Selden Rose, 1916, p. 12, había destacado el valor de este capítulo, que relacionó con la actitud moralizante y satírica de Quevedo hacia las costumbres de su tiempo.

88. Se trata de una idea bastante extendida; el propio Quevedo menciona líneas más adelante una afirmación de Cicerón en este sentido: «I estas costumbres son hijas de su nezesidad; asi lo dijo Ciçeron, el que todo lo dijo mejor que todos, mejorandolo, i lo que no, de suerte que nadie lo pudiese mejorar: tomo 2, oracion XV, De la ley Agraria, contra P. Seruilio Rullo, al fin: «no se enjendran en los hombres las costumbres tanto de la estirpe i linaje o jenerazion, como de aquellas cosas que les son administradas de la naturaleza del lugar i de la costumbre de la vida con que nos criamos i vivimos» (pp. 80-81, ff. 123r-123v). 
introducción muestran claramente su unidad:

Como sea verdad asegurada por los philosophos que de la buena o mala templanza de los humores resultan las complexiones en los cuerpos, i de ellas las costumbres, las quales, aunque suele correjir la rrazon, por la mayor parte muestran, o en las obras o en la intenzion, imperiosamente su malizia, es sin duda que Espańa, teniendo tierra templada i çielo sereno, causara semejantes efetos en vmores i condiziones, como se ue, pues ni la frialdad nos haze flematicos y perezosos como a los alemanes, ni el mucho calor inutiles para el trabajo como a los negros i a los indios; pues, templada la vna calidad con la otra, produze bien castigadas costumbres (p. 80, ff. 122r-122v).

Asi que concluimos que las costumbres propias i primeras despańa fueron en todo hijas de la templanza de su çielo i de la naturaleza del lugar, i por eso modestas, moderadas i segun justa lei i diziplina (pp. 81-82, f. 125v).

Entre estos pasajes, el exordio menciona como virtudes esenciales de España «la lealtad a los prinçipes i relijiosa la obedienzia a las leyes, i el amor a los jenerales i capitanes» (p. 80, f. 122v). De esta última idea se deriva una digresión que amplifica las glorias militares de los españoles, motivo clásico en las laudes Hispaniae. Dicho valor hispano se explica como defensa ante los ataques de otros pueblos a causa de sus riquezas, idea que se amplifica con una cita de Cicerón y se ilustra con varios exempla de diversas naciones cuyos caracteres fueron moldeados por la naturaleza de su emplazamiento (pp. 80-81, ff. 123r-125r). Termina la serie con un ejemplo singular, el de Roma. Destaca no solo por su importancia histórica, sino porque ejemplifica una frontera entre las glorias militares que logró en la guerra y su posterior decadencia, a la que cayó arrastrada por los vicios de la paz. En ese espejo ve Quevedo reflejada la situación de España; combinando la advertencia con un elogio de su virtud guerrera, Quevedo desconfía del sosiego que goza Espańa en tiempos de Felipe III y recuerda las constantes amenazas que la acechan; cierra el pasaje la siempre eficaz alegoría náutica, que aquí identifica el mar agitado con sus enemigos, y la orilla que frena las olas con su papel de garante de la cristiandad:

Mientras tubo Roma a quien temer i enemigos, ique diferentes costumbres tubo! ¡Como se egerçito en las armas! ¡Que pechos tan valerosos ostento al mundo! Mas luego que onrraron sus deseos perezosos al otio bestial con nombre de paz santa, ique vizio no se apodero de ella!, ji que torpeza no embarazo los animos que antes vastaron a sujetar el mundo! Viose entonzes que la prudenzia de los ombres sobra para uenzer el mundo; mas no sabe benzerse a si. I si es uerdad que a la imbidia de los enemigos i al miedo preçioso que se les tiene, (llamole asi por efeto el que haze), se deue el cuiidado i diziplina de los persegidos i invidiados, largo es sin duda en Espańa este fruto, pues como tierra que por todas partes se ue aduertida de ojos, enemigos de sus prinzipios, a que se ejerçita toda en defensas de su virtud, i asi en esta poca paz que alcanzamos, em parte maliziosa, el largo abito a las santas costumbres de la gerra la sustenta en ellas, aunque a mi opinion España nunca goza de paz, 
solo descansa, como aora, del peso de las armas, para tornar a ellas con maior fuerza i nuevo aliento. I son a todos como a ella importantes las armas suias, pues, a no auerlas, corriera sin limites la soberbia de los turcos i la insolenzia de los erejes, i gozaran en las Indias seguros los idolos su adorazion, de suerte que es orilla deste mar cuia gloria es la obediencia destas olas que solamente la tocan para deshazerse (p. 81, ff. 124r-125r).

Tras el exordio, el grueso del capítulo se dedica a contrastar las virtudes del pasado con los vicios de los tiempos presentes. Comienza recorriendo las excelencias de antańo, donde el valor guerrero es el primer rasgo que se destaca apoyado en diversas autoridades. Un pasaje de Aristóteles (Politicorum 7, 2) le da pie para una nueva digresión - no demasiado extensa- donde contrasta los túmulos de los antiguos españoles, adornados con los cadáveres de los vencidos, con las ostentosas galas de los de su tiempo. Al valor militar sigue una breve referencia laudatoria a la santidad y virtud de los antiguos, para detenerse a continuación en la ponderación de sus leyes, de las que destaca su procedencia divina y su rigor. Retomando una idea expuesta al comienzo de este capítulo ${ }^{89}$, exalta a continuación la lealtad con sus reyes, fuesen estos buenos o malos.

Ese cúmulo de antiguas virtudes desemboca en el principio de la protección divina; se incluye así una serie de ejemplos históricos de triunfos hispanos como pueblo elegido de Dios: las Navas de Tolosa, las hazañas del Cid y la conquista de las Indias. El elogio de las costumbres antiguas se cierra con un párrafo que responde a las exigencias de una recapitulación; por una parte, recurre a la eficaz tópica de lo indecible; por otra, avanza la censura de las costumbres de su tiempo que desarrollará a continuación, y la vincula al pasado glorioso en el que España descansa confiada:

Prolijo fuera i vanaglorioso en querer contar por menudo todas las cosas que nos suzedieron a los espańoles gloriosamente en los dias que an pasado, sin callar que a auido hijo suio que llora estos tiempos i el verla viuda em parte del antiguo vigor, i osa dezir que la confianza de auerle tenido introduze descuiido de conseruarle (p. 84, f. 128v).

La censura de las costumbres presentes repasa una serie de comportamientos que comienza con el dinero, la gula y el juego, y sigue con el gasto de las mujeres en adornos y galas, el afeminamiento de los hombres -también dados a dichos adornos-, la homosexualidad y los interesados cuernos de los maridos sufridos ${ }^{90}$.

Es evidente que esa crítica a la sociedad de su tiempo alcanza en último término a su gobierno. España defendida es, en este sentido, un panegírico

89. Lo indicó ya Roncero, 2000, p. 31.

90. Son estas actitudes que aparecen censuradas en otras muchas obras de Quevedo: los Sueños, La Hora de todos, Marco Bruto... y también en textos burlescos como Premática del Tiempo, Vida de Corte o Papel de las cosas ocurridas en la Corte, por abecedario. Dejando a un lado las lógicas variaciones impuestas por las circunstancias y género de cada obra, se observa una constante en las principales preocupaciones del escritor. Véase Roncero, 2000, pp. 33-36. 
que en ocasiones se sirve de la alabanza para censurar ${ }^{91}$. Resulta, pues, imprescindible contrarrestar el efecto de esas alusiones negativas, y para ello Quevedo coloca dos pasajes donde alaba la figura de Felipe III como única esperanza de salvación:

Llegaran estas cosas a desesperar de remedio a España, si la modestia i uirtud i christiandad de don Filipe 3, nuestro señor, no diera freno a estas cosas con su exemplo [...] I asi se ben oi muchos pobres virtuosos en altos lugares, mas por cuerda aduertenzia de don Philipe 3, que por costumbre que vbiese de premiar venemeritos (pp. 84-85, ff. 129r-129v).

Al fin se ue en estado Espańa, por nuestros peccados, que a no interuenir Rey tan santo i tan justo i onesto, i ministros tan conformes a su virtud i tan zelosos de su opinion i del seruizio de Dios i del aumento del Reyno, desesperara a las bueltas del tiempo de poderla traer a peor estado (p. 85, f. $130 \mathrm{v})$.

Los elogios al pasado virtuoso terminaban con una recapitulación que los unía a la censura del presente. En equilibrada dispositio, Quevedo coloca otro pasaje similar al final del recorrido por los vicios de su época. Ambos textos dibujan un perfil de riguroso censor de su patria que legitima las alabanzas con que la exalta y las duras críticas hacia las naciones extranjeras:

Esto dize despańa vn hijo suio, ingrato con poca uerdad ${ }^{92}$ de mi propia tierra, con tener el referido nombre de madre la patria, asi lo que es en su abono como lo que no lo es, para poder con mas libertad dezir de las demas naziones la uerdad, no auiendome perdonado a mi mismo, despues de auer respondido a las calumnias arriba referidas, que son epilogo de las muchas que scriuio su autor (p. 85, f. 130v).

A este capítulo, equilibradamente dispuesto, le siguen dos folios en blanco (ff. 131 y 132); tras ellos (f. 133r) se copia una cita de Sexto Pompeyo Festo (De significatione verborum, lib. X) ${ }^{93}$ donde Quevedo define la voz manducus ('tarasca') y la utiliza como metáfora que convierte las dentelladas de esa figura en gráfica expresión de su alma de satírico. Este pasaje no parece constituir el final del capítulo $\mathrm{V}$, sino más bien otra anotación del manuscrito ${ }^{94}$.

91. Sobre esta técnica manifestó Quevedo lo siguiente en Virtud militante: «Estrataxema muchas vezes bien lograda, para reprehender a los monarchas, alabarlos, de lo que no hazen, ni tienen, ni quieren» (p. 159). Véanse también las consideraciones que en el terreno político hace E. Ma. Díaz Martínez, 2000, pp. 108-109.

92. Esta frase fue escrita posteriormente, con trazo más fino.

93. Sexto Pompeyo Festo fue un gramático latino del siglo II o III d.C. Destacó por haber dejado escrito un glosario latino titulado Sexti Pompei Festi De Significatione Verborum, una compilación o resumen de la obra de M. Verrio Flaco De Significatione Verborum. El libro de Festo es muy importante para el conocimiento de las antigüedades latinas, aunque ha llegado a nosotros solo en parte, a través de un glosario establecido por Pablo Diácono en el siglo VIII.

94. Ya lo señaló Roncero, 1997, pp. 219-220. Tras la cita, los ff. 133v, 134 y 135 están en blanco, como sucede en todos los finales de capítulo. Aunque no es fácil asegurar cuál es el lugar que corresponde a ese pasaje (hay marcas similares en otros folios del manuscrito, como en la 


\section{Capítulo VI: «Del falso orijen de las gentes» (FF. I36r-I38v)}

Es un capítulo muy breve, truncado en un final abrupto que lo deja incloncluso. Comienza con unas advertencias generales que, por una parte, constatan los ataques de los extranjeros contra los orígenes hispanos y, por otra, la desmedida ostentación que hacen de los suyos. Como es preceptivo en el inicio, se expone luego su finalidad, rasgo que se ha respetado en toda la obra. Aquí se tratará de aclarar la verdad sobre el origen de los pueblos por encima de los condicionamientos propios de los panegíricos, una actitud que ya se ha observado en varios lugares de España defendida.

Respetando el "previlegio de las escrituras divinas», el primer pueblo es el de los hebreos. Se desarrollan aquí una serie de consideraciones sobre el lugar donde habitaron. Quevedo vuelve a utilizar aquí dos tipos de razones habituales en los textos que abordaban los orígenes de los pueblos, y que también lo han sido en las páginas de España defendida: las propuestas etimológicas y los condicionamientos del clima y la geografía. La conclusión es la mayor antigüedad de las monarquías orientales y la más reciente población de los lugares occidentales, más fríos y húmedos. El capítulo, y con él lo conservado de la obra, queda truncado en este punto ${ }^{95}$.

El análisis de la estructura y argumentación de España defendida arroja una serie de conclusiones sobre el carácter de la obra y el modo de proceder de Quevedo. En primer lugar, confirma un hecho evidente, pero que debe tenerse en cuenta al estudiar cualquier aspecto del texto: estamos ante un escrito inacabado que, en consecuencia, carece de una estructura equilibrada en la longitud de sus capítulos, e incluye anotaciones que rompen su discurso. Los folios en blanco al final de cada capítulo y las anotaciones con marcas que remiten a partes del texto muestran con claridad ese proceso de revisión e integración de nuevos materiales.

Esta característica se repetirá en la trayectoria prosística de Quevedo, donde encontramos otras obras inconclusas, cuando no proyectos que parecen no haberse llevado a cabo. Probablemente el afán de Quevedo por abarcar múltiples géneros, y la revisión a la que sometió a muchos de sus textos, expliquen que una vida no haya sido suficiente para finalizar de forma «redonda» una obra literaria acaso inabarcable para un solo escritor.

hoja segunda o el f. 59v), dichas marcas aparecen en la parte superior de los ff. $128 \mathrm{v}$ y $129 \mathrm{v}$, delimitando una parte del texto especialmente virulenta en las censuras a los vicios de la sociedad española del tiempo de Quevedo.

95. El contenido hasta el final del manuscrito es el siguiente: cuatro folios en blanco (ff. 139142); un folio (f. 143) con anotaciones sobre la función del Praeco y el Grex en las comedias de Plauto; veinte folios en blanco (ff. 144-163); una lista de «Reyes asi verdaderos como fabulosos i dudosos despaña» (ff. 164-165r); varios folios en blanco (ff. 165v-174v); una cita bíblica (f. 175r): «Judith. Cap. XIIII. Ecce enim Holofernes iacet in terra, et caput eius non est in eo»; varios folios en blanco (ff. 175v-189r); una cita de Plauto que incluyó en los folios 90v-91r del capítulo IV. 
En segundo lugar, y vinculado a lo inacabado del texto, destaca la tendencia a la digresión, que en varias ocasiones prolonga un pasaje o capítulo que habrían resultado más proporcionados sin ella. Relacionado con la digresión está un tercer rasgo: Quevedo usa sobre todo la amplificación acumulativa como procedimiento de argumentación, intentando convencer por medio de un aluvión de autores, lugares y citas que, al tiempo, sirven de explicable alarde erudito en un escritor que iniciaba su camino en asuntos graves. Finalmente, España defendida es, retóricamente, un ejemplo de panegírico organizado como refutatio; estas dos esferas explican la mayoría de los recursos utilizados en el texto, y acaso también el uso argumentativo que hace Quevedo de no pocos datos e informaciones de los que interesan no tanto su detalle como su conveniencia al propósito.

Junto a estas características, España defendida ya deja asomar al que será maestro en usar las técnicas de argumentación para abrirse camino en el mar político y literario de su tiempo. Casi todos los recursos que desplegará en sus memoriales y tratados más destacados aparecen ya en este texto temprano. Es verdad que la acumulación de hipótesis lingüísticas, autoridades y virtudes patrias desborda en ocasiones la lectura y dificulta la percepción de finuras argumentativas. Sin embargo, puede apreciarse ya el canónico inicio de los capítulos indicando con claridad su objeto y futuro discurrir; también el hábil uso de silogismos, concessiones, dilemmata, loci a comparatione y otros tipos de razonamiento, a menudo situados como eficaz remate de una acumulación de autores. Otras veces será el uso argumentativo de la cita el que servirá para refutar al rival, cuando no la concreta enseñanza del exemplum o la plasticidad de la metáfora. La vehemencia aparecerá también en su importante papel argumentativo como motora de los afectos, pues bastantes acumulaciones se acompañan de figuras de reiteración y entonación que hacen más expresivo su mensaje; en otras ocasiones, serán las pullas y los insultos airados los que desautorizarán al rival esgrimiendo como razón la fe y la ortodoxia católica.

No conservamos el texto definitivo y completo, por lo que estas conclusiones deben tomarse con cautela, pues no es posible realizar una valoración precisa de lo que habría sido el resultado final. Aun así, los futuros tratados de Quevedo denotan un mayor equilibrio estructural, tanto en la extensión de las partes y capítulos como en la moderación de acumulaciones y digresiones. Si este temprano borrador pretendía convencer por la cantidad, los textos futuros buscarán potenciar otras vías argumentativas aquí ya apuntadas. Parece, en todo caso, un proceso lógico en la formación y evolución literaria de un escritor, aunque este sea Quevedo. 


\section{BibliografíA}

Aetna, recensuit, notasque Ios. Scaligeri, Frid. Lindenbruchii, et suas addidit Fridericus Iacob., Lipsiae, 1826.

Aldrete Bernardo de, Del origen y principio de la lengua castellana ò romance que oi se usa en España, edición facsimilar y estudio de Lidio Nieto Jiménez, Madrid, CSIC, 2 vols. 1972-1975.

- Varias antiguedades de España, Africa y otras provincias, Amberes, a costa de Iuan Hasrey: typis Gerardi Wolsschatii, et Henrici Aertsii, 1614.

Azaustre Galiana Antonio, Paralelismo y sintaxis del estilo en la prosa de Quevedo, Santiago de Compostela, Universidad, 1996.

— «La argumentación retórica en el Memorial por el patronato de Santiago, de Francisco de Quevedo", Edad de Oro, 19, 2000, pp. 29-64.

— «El uso retórico de las Autoridades en las polémicas literarias sobre el estilo culto», en A zaga de tu huella. Homenaje al profesor Cristóbal Cuevas, coord. Salvador Montesa, Málaga, Universidad de Málaga, 2005, vol. 1, pp. 309-333.

- ed., Francisco de Quevedo, Obras crítico-literarias, en Obras completas en prosa, vol. 1, dir. A. Rey, Madrid, Castalia, 2003.

Barros Aguilera Manuel, Los falsos cronicones contra la historia, Granada, Editorial Universidad de Granada, 2004.

Barros Aguilera Manuel y Mercedes García-Arenal, eds., Los plomos del Sacromonte: invención y tesoro, Valencia, Universitat de València, 2006.

Binotti Lucía, La teoría del "castellano primitivo»: nacionalismo y reflexión lingüística en el Renacimiento español, Münster, Nodus, 1995.

Blázquez Martínez José María, «Economía de Hispania al final de la República romana y a comienzos del Imperio según Estrabón y Plinio», en Estudios de Historia Económica, vol. I, no 78, 1971, pp. 57-143.

Bussell Thompson B., ed., Rosal, Francisco del, La Razón de algunos refranes. Alfabetos tercero y cuarto de Origen y Etimología de todos los vocablos, London, Tamesis Books, 1975.

Caminero Juventino, "El léxico hebraico y su significación en la obra de Quevedo», Letras de Deusto,17, enero-junio, 1979, pp. 53-85.

Carrera de la Red Avelina, El problema de la lengua en el Renacimiento español, Valladolid, Universidad de Valladolid. Secretariado de Publicaciones, 1988.

Cicerón, De inventione, ed. bilingüe (latín-francés) de Guy Achard, Paris, Les Belles Lettres, 1994.

- Pro A. Licinio Archia Oratio, texte établi par Félix Gaffiot, Paris, Les Belles Lettres, 1959.

Cirot Georges, Les histoires générales d'Espagne entre Alphonse X et Philippe II: (12841556), Bourdeaux, Feret \& Fils, 1905.

Curtius Ernst Robert, Literatura europea y Edad Media latina, traducción española de M. Frenk y A. Alatorre, México, FCE, 1981 (3ª reimp.; primera edición, Berna, 1948).

Davis Gifford, «The development of a national theme in medieval castilian literature», Hispanic Review, III, 1935, pp. 149-161.

Díaz Martínez Eva María, ed., Francisco de Quevedo, Discurso de las privanzas, Pamplona, Eunsa, 2000. 
Godoy Alcántara José, Historia crítica de los falsos cronicones, Madrid, Rivadeneyra, 1868.

Gómez Moreno Ángel, España y la Italia de los humanistas, Madrid, Gredos, 1994.

Granada fray Luis de, Ecclesiasticae rhetoricae sive de ratione concionandi libri sex, Olysipone, Antonius Riberius, 1576; manejo la traducción castellana, Los seis libros de la Retórica Eclesiástica o de la manera de predicar, vertidos al español de orden del Ilmo. Obispo de Barcelona, Barcelona, 1770, en Biblioteca de Autores Espańoles, 11, Madrid, Rivadeneyra, 1879, pp. 466-642.

Hermógenes Teón Aftonio, Ejercicios de retórica, traducción española de Ma Dolores Reche Martínez, Madrid, Gredos, 1991.

Herrero García Miguel, Ideas de los españoles en el siglo XVII, Madrid, Gredos, 1966.

Jauralde Pou Pablo, "Una aventura intelectual de Quevedo, España defendida», en Quevedo a nueva luz: escritura y politica, eds. Lía Schwartz y Antonio Carreira, Málaga, Universidad de Málaga, 1997, pp. 45-58.

- Francisco de Quevedo (1580-1645), Madrid, Castalia, 1998.

Lausberg Heinrich, Manual de retórica literaria. Fundamentos de una ciencia de la literatura, traducción española de José Pérez Riesco, Madrid, Gredos, 1966-1969, 3 vols.

Lawrance Jeremy, "The spread of lay literacy in late medieval Castile», Bulletin of Hispanic Studies, 62, 1985, pp. 79-94.

López Madera Gregorio, Excelencias de la monarchía y reyno de España, Sevilla, Diego Fernández de Córdoua, 1597.

Mantuano Pedro, Advertencias a la Historia del Padre Ivan de Mariana, Madrid, Imprenta Real, 1613 (segunda impresión; fue impresa en latín en 1592 y en castellano en 1601).

Mariana Juan de, Historia general de España, Madrid, Joaquín de Ibarra, 1780.

Menéndez Pidal Ramón, La España del Cid, Madrid, Editorial Plutarco, 1929.

Morales Ambrosio de, Los cinco libros postreros de la Corónica general de España que continuaba Ambrosio de Morales, Córdoba, Gabriel Ramos Bejarano, 1586.

Munro Hugh Andrew Johnstone, ed., Aetna, Cambridge, Cambridge University Press, 1867.

Nieto Jiménez Lidio, ed., Bernardo de Aldrete, Del origen y principio de la lengua castellana ò romance que oi se usa en España, vol. II, Ideas lingüísticas de Aldrete, Madrid, CSIC, 1975.

Obras de Garci Lasso de la Vega con anotaciones de Fernando de Herrera (Sevilla, Alonso de la Barrera, 1580), edición facsímil con un «Estudio bibliográfico» por Juan Montero, Sevilla, Universidades de Córdoba, Huelva y Sevilla / Grupo PASO, 1998.

Ovidio, Fasti, texte établi, traduit et commenté par R. Schilling, Paris, Les Belles Lettres, 1992-1993 (2 vols.).

Pascual Recuero Pascual, "Quevedo del alef a la zeda", Miscelánea de estudios árabes y hebraicos, 31, 1982, pp. 141-159.

Peraita Carmen, Quevedo y el joven Felipe IV. El principe cristiano y el arte del consejo, Kassel, Reichenberger, 1997.

Plata Parga Fernando, «Edición de las Controversias de Séneca, texto inédito de Francisco de Quevedo», La Perinola. Revista de Investigación Quevediana, 5, 2001, pp. 207-275. 
Plauto, Stichus, with an english translation by P. Nixon, London-Cambridge Mass., William Heinemann-Harvard University Press, 1968 (vol. 5).

Quevedo Francisco de, Cuento de cuentos, edición de A. Azaustre Galiana en Obras completas en prosa, vol. 1, dir. A. Rey, Madrid, Castalia, 2003.

- La culta latiniparla, edición de A. Azaustre Galiana en Obras completas en prosa, vol. 1, dir. A. Rey, Madrid, Castalia, 2003.

- España defendida y los tiempos de ahora, de las calumnias de los noveleros y sediciosos, edición de Robert Selden Rose, Madrid, Imprenta Fortanet, 1916 (editada también en el Boletín de la Real Academia de la Historia, LXVIII, 1916, pp. 513-543 y 629639, LXIX, 1916, pp. 140-182).

- Grandes anales de quince días, edición de V. Roncero López en Obras completas en prosa, vol. 3, dir. A. Rey, Madrid, Castalia, 2005.

- Virtud militante. Contra las quatro pestes del mundo, inuidia, ingratitud, soberbia, avarizia, ed. de A. Rey, Santiago de Compostela, Universidad de Santiago de Compostela, 1985.

Quintiliano, Institutio Oratoria, ed. bilingüe (latín-francés) de J. Cousin, Paris, Les Belles Lettres, 1975-1980, 7 vols.

Rey Alfonso, ed., Francisco de Quevedo, Poesía moral (Polimnia), segunda edición revisada y ampliada, Madrid, Tamesis, 1999.

Rico Francisco, «Laudes litterarum: Humanismo y dignidad del hombre en la España del Renacimiento", en Homenaje a Julio Caro Baroja, eds. Antonio Carreira et alii, Madrid, Centro de Investigaciones Sociológicas, 1978, pp. 895-914.

Roncero López Victoriano, "Las "laudes Hispaniae” de san Isidoro a Quevedo", Analecta Malacitana, 16.1, 1993, pp. 81-92.

— «Aproximación al estudio y edición de la España defendida», La Perinola. Revista de Investigación Quevediana, 1, 1997, pp. 215-234.

— «Las fuentes humanísticas en la historiografía quevediana: los reyes primitivos en la España defendida», La Perinola. Revista de Investigación Quevediana, 3, 1999a, pp. 269-292.

— «La defensa de la literatura española en la España defendida», en Rostros y máscaras: personajes y temas de Quevedo, eds. Ignacio Arellano y Jean Canavaggio, Pamplona, Eunsa, 1999b, pp. 197-218.

- El humanismo de Quevedo: filología e historia, Pamplona, EUNSA (Anejos de La Perinola 6), 2000.

—, ed., Francisco de Quevedo, España defendida, Pamplona, Eunsa, 2012 (en prensa en el momento de entregar este trabajo para su impresión).

Rosal Francisco del, Diccionario etimológico: "Alfabeto» primero de "Origen y Etimología de todos los vocablos originales de la lengua castellana», edición facsimilar y estudio de Enrique Gómez Aguado, Madrid, CSIC, 1992.

- El origen de los nombres, edición de Antonio José Mialdea, Córdoba, Berenice, 2006.

- La Razón de algunos refranes. Alfabetos tercero y cuarto de Origen y Etimología de todos los vocablos, introducción, edición y notas por B. Bussell, Thompson, London, Tamesis Books, 1975.

Ruiz Castelao Ofelia, La historiografía del voto de Santiago, Santiago de Compostela, Universidad de Santiago de Compostela, 1985. 
Sánchez Alonso Benito, Historia de la historiografía española, Madrid, CSIC, 1941, 3 vols.

Sarmiento Ramón, «Los grandes temas de la tradición filológica española», en Homenaje a Eugenio de Bustos Tovar, Salamanca, Ediciones de la Universidad de Salamanca, 2002, vol. 2, pp. 903-924.

Schwartz Lía, «Entre Propercio y Persio: Quevedo, poeta erudito», La Perinola. Revista de Investigación Quevediana, 7, 2003, pp. 367-395.

Selden Rose Robert, ed., Francisco de Quevedo, España defendida y los tiempos de ahora, de las calumnias de los noveleros y sediciosos, Madrid, Imprenta Fortanet, 1916 (editada también en el Boletín de la Real Academia de la Historia, LXVIII, 1916, pp. 513-543 y 629-639, LXIX, 1916, pp. 140-182).

Tate Robert Brian, «La geografía humanística y los historiadores del siglo XV», en Actas del cuarto Congreso Internacional de Hispanistas, coordinado por Eugenio de Bustos Tovar, Salamanca, Universidad de Salamanca, 1982, vol. 2, pp. 691-698.

Terracini Lore, Lingua come problema nella letteratura spagnola del Cinquecento (con una frangia cervantina), Torino, Stampatori, 1979. 